\title{
Impact of transported background ozone inflow on summertime air quality in a California ozone exceedance area
}

\author{
D. D. Parrish ${ }^{1}$, K. C. Aikin ${ }^{1,2}$, S. J. Oltmans ${ }^{3}$, B. J. Johnson ${ }^{3}$, M. Ives ${ }^{4}$, and C. Sweeny ${ }^{3}$ \\ ${ }^{1}$ NOAA ESRL Chemical Sciences Division, 325 Broadway, Boulder, CO 80305, USA \\ ${ }^{2}$ CIRES, University of Colorado, Boulder, CO 80309, USA \\ ${ }^{3}$ NOAA ESRL Global Monitoring Division, 325 Broadway, Boulder, CO 80305, USA \\ ${ }^{4}$ Humboldt State Marine Lab, 570 Ewing St., Trinidad Head, CA, 95570, USA
}

Received: 14 May 2010 - Published in Atmos. Chem. Phys. Discuss.: 30 June 2010

Revised: 11 October 2010 - Accepted: 12 October 2010 - Published: 27 October 2010

\begin{abstract}
Ozone sondes launched from Trinidad Head, California provide a measure of background $\mathrm{O}_{3}$ transported ashore, and allow an evaluation of the impact of this transport on air quality in California's Northern Sacramento Valley. A strong summertime vertical $\mathrm{O}_{3}$ gradient and correlation analysis indicate that $\mathrm{O}_{3}$-rich air from above the marine boundary layer is transported to the surface. Surface $\mathrm{O}_{3}$ is found to increase proportionally to the transported background. At the surface site experiencing the highest $\mathrm{O}_{3}$ concentrations, the mean maximum daily 8 -h average (MDA8) $\mathrm{O}_{3}$ on exceedance days (i.e. those days when $\mathrm{MDA} 8 \mathrm{O}_{3}$ exceeds $75 \mathrm{ppbv}$ ) is $20 \mathrm{ppbv}$ higher than on non-exceedance days. The transported background $\mathrm{O}_{3}$, as measured $22 \mathrm{~h}$ earlier by the Trinidad Head sondes, accounts for more than half (11 ppbv) of this difference. This finding contrasts with conclusions from model calculations that indicate the US policy relevant $\mathrm{O}_{3}$ background is generally $15-35 \mathrm{ppbv}$, and that it is lower, rather than higher, during pollution episodes. The present work indicates that $\mathrm{O}_{3}$ transported on hemispheric scales substantially impacts air quality in some areas of the US.
\end{abstract}

\section{Introduction}

The US National Ambient Air Quality Standard (NAAQS) for ground-level ozone $\left(\mathrm{O}_{3}\right)$ was recently lowered to $75 \mathrm{ppbv}$ (0.075 ppmv) based upon an 8-h average (US Environmental Protection Agency (EPA), 2006). The NAAQS is intended to provide a margin of safety between background levels of $\mathrm{O}_{3}$ and those concentrations above which exposure becomes harmful to public health or welfare. The EPA defines policy

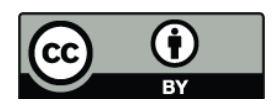

Correspondence to: D. D. Parrish (david.d.parrish@noaa.gov) relevant background (PRB) $\mathrm{O}_{3}$ concentrations as those that would exist in the US in the absence of anthropogenic emissions from North America (EPA, 2006). The $\mathrm{PRB} \mathrm{O}_{3}$ concentration includes that formed through photochemical reactions involving precursors from biogenic sources, wildfires and lightning, as well as $\mathrm{O}_{3}$ transported to the US from outside North America or from the stratosphere. The NAAQS assumes that $\mathrm{PRB}_{3}$ concentrations are in the 15 to $35 \mathrm{ppbv}$ range, primarily based upon model results (e.g. Fiore et al., 2002, 2003). Importantly, this modeling work found that the PRB during exceedance periods was lower than average $\left(<15\right.$ ppbv) due to enhanced $\mathrm{O}_{3}$ destruction during the stagnation periods that drive many exceedances. While these results may be appropriate for much of the US, they may not be applicable to the western US where inflow of marine air has a significant influence on surface $\mathrm{O}_{3}$ concentrations. Here we use the term marine air to denote air uninfluenced by recent North American emissions transported to the continent from the Pacific Ocean, both within the marine boundary layer (MBL) and in the free troposphere (FT). The goal of the present study is to use sonde and surface measurements to derive an observationally based estimate of the impact that transported background $\mathrm{O}_{3}$ has on summertime air quality in one example $\mathrm{O}_{3}$ non-attainment area - California's Northern Sacramento Valley (NSV).

The NSV, lying directly inland from an $\mathrm{O}_{3}$ sonde launch site on the coast of Northern California, provides a unique opportunity to investigate the impact of transported background $\mathrm{O}_{3}$ on North American air quality. The NSV (Fig. 1) is located $\approx 160 \mathrm{~km}$ inland from the Pacific coast. Despite relatively low population (Redding with approximately 90000 people is the largest city) this valley is designated as a non-attainment area under the California state $\mathrm{O}_{3}$ standard, and observed mixing ratios (see color scale in Fig. 1) exceed the 75 ppbv NAAQS. At northern mid-latitudes, the prevailing winds in the lower FT are westerly, which brings marine

Published by Copernicus Publications on behalf of the European Geosciences Union. 


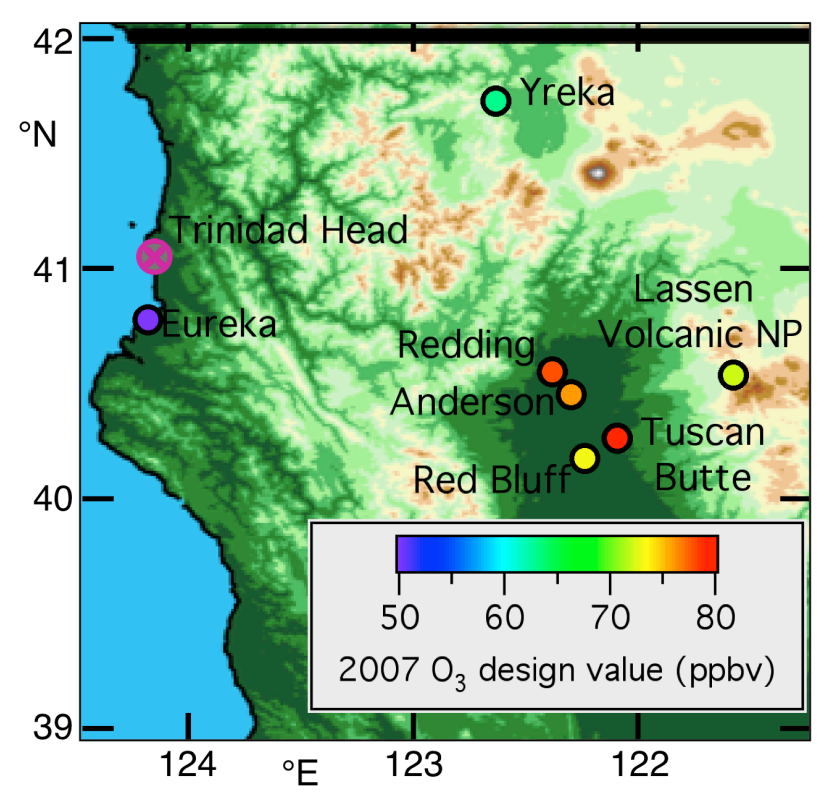

Fig. 1. Map of Northern California $\mathrm{O}_{3}$ measurement sites. The heavy line at the top is the Northern California border. The Northern Sacramento Valley contains the Redding, Anderson, Red Bluff and Tuscan Butte sites. Yreka is located in an isolated valley (Shasta Valley) north of the Sacramento Valley. Each symbol color indicates the 3-year average of the fourth-highest $\mathrm{MDA} 8 \mathrm{O}_{3}$ mixing ratio (i.e. $\mathrm{O}_{3}$ design value), which is the metric upon which the NAAQS is based. The surface elevation is indicated by the color shading with dark green at sea level, shading to light tan near $1 \mathrm{~km}$, with darker browns and white indicating the highest altitudes above $3 \mathrm{~km}$.

air ashore from over the Pacific. Thus, the $\mathrm{O}_{3}$ sonde data provide a characterization of the background $\mathrm{O}_{3}$ impacting the upwind edge of the continent, both within the MBL and the FT.

To characterize the impact of transported background $\mathrm{O}_{3}$ on the NSV, it is critical to determine the altitude from which marine air is transported into the valley. The California coastal mountain ranges separate the NSV from the Pacific environment, and their crest is at elevations of $\geq 1 \mathrm{~km}$, which serve to isolate the valley from marine surface air inflow. Importantly, a strong positive vertical $\mathrm{O}_{3}$ gradient is present at the Pacific coast (Oltmans et al., 2008), so if air were mixed from higher altitudes down to the valley surface, the marine impact would be larger than expected from $\mathrm{O}_{3} \mathrm{ob}$ servations made at the coast within the MBL. In this work we use altitude dependent correlations between the Trinidad Head sonde measurements and NSV surface measurements to show that marine air inflow is predominately transported down from altitudes above $1 \mathrm{~km}$. This downward transport allows long-range transport of background $\mathrm{O}_{3}$ to substantially affect air quality within the valley.
Earlier work has documented transport episodes of elevated $\mathrm{O}_{3}$ (Hudman et al., 2004) and aerosol (McKendry et al., 2001) concentrations to coastal surface sites in North America following transport across the Pacific. These events occurred in springtime and involved synoptic scale systems interacting with coastal topography. In this work we focus on summer, the $\mathrm{O}_{3}$ exceedance season, when mechanisms associated with the diurnal cycle of land surface heating control the transport of air into the NSV.

The distinction between $\mathrm{PRB} \mathrm{O}_{3}$ and transported background $\mathrm{O}_{3}$ deserves particular attention. $\mathrm{PRB} \mathrm{O} \mathrm{O}_{3}$ defined above is a model concept that cannot be directly measured, since it is not possible to eliminate the impact of North American emissions in ambient measurements. In this work the transported background $\mathrm{O}_{3}$ is taken to mean the $\mathrm{O}_{3}$ mixing ratios measured at a given site in the absence of local influences. It can be determined directly from measurements, (e.g. Derwent et al., 2007; Parrish et al., 2009). Throughout this paper the term "background $\mathrm{O}_{3}$ " refers to this latter meaning, and we will return to this distinction in the final section of the paper.

This paper is organized as follows. Following a brief description of the data sets that are examined (Sect. 2), the systematic variations of $\mathrm{O}_{3}$ in the marine and continental environments, including the vertical gradient of $\mathrm{O}_{3}$ determined from the Trinidad Head ozone sondes, are discussed in Sect. 3. Utilizing this context of these systematic variations, Sect. 4 uses correlations of $\mathrm{O}_{3}$ between the various data sets to examine the transport of marine air inland, and to approximately quantify the impact of the transported marine air on observed $\mathrm{O}_{3}$ at continental surface sites. Section 5 briefly discusses the transport patterns responsible for the mixing down of air from higher altitudes to the surface, while Sect. 6 gives an approximate quantification of the role that transported background $\mathrm{O}_{3}$ plays in ozone exceedances in the NSV. Finally, Sect. 7 summarizes the conclusions and discusses the significance of the results for North American air quality control policies.

\section{Data sets analyzed}

Table 1 summarizes the data sets utilized in this study, and gives some information regarding the measurement sites. To our knowledge, the Table includes all large data sets of continuous $\mathrm{O}_{3}$ measurements that have been made in this Northern California region. The California Air Resources Board has continuously monitored surface $\mathrm{O}_{3}$ at six sites in Northern California beginning in 1990, and the National Park Service has maintained a higher elevation site at Lassen Volcanic National Park since 1987. The Global Monitoring Division of NOAA/ESRL began launching $\mathrm{O}_{3}$ sondes from Trinidad Head, California in 1997, generally on a weekly basis, and began continuous surface measurements in 2002 at the Trinidad Head California Baseline Observatory. Nearly 
Table 1. Ozone data sets investigated in the present analysis.

\begin{tabular}{|c|c|c|c|c|}
\hline \multicolumn{5}{|c|}{ Ozone Sonde Launch Site } \\
\hline Trinidad Head & $\begin{array}{l}\text { August 1997- } \\
\text { November } 2008\end{array}$ & $\begin{array}{l}41^{\circ} 3^{\prime} \mathrm{N} \\
124^{\circ} 9^{\prime} \mathrm{W}\end{array}$ & $\begin{array}{l}- \\
-\end{array}$ & NOAA GMD $^{\mathrm{a}}$ \\
\hline \multicolumn{5}{|c|}{ North Sacramento Valley Surface Sites } \\
\hline Redding & $\begin{array}{l}\text { May 1990- } \\
\text { December } 2008\end{array}$ & $\begin{array}{l}40^{\circ} 33^{\prime} \mathrm{N} \\
122^{\circ} 23^{\prime} \mathrm{W}\end{array}$ & 149 & $\begin{array}{l}\text { California Air Resources } \\
\text { Board }\end{array}$ \\
\hline Anderson & $\begin{array}{l}\text { June } 1993- \\
\text { December } 2008\end{array}$ & $\begin{array}{l}40^{\circ} 27^{\prime} \mathrm{N} \\
122^{\circ} 18^{\prime} \mathrm{W}\end{array}$ & 131 & $\begin{array}{l}\text { California Air Resources } \\
\text { Board }\end{array}$ \\
\hline Tuscan Butte & $\begin{array}{l}\text { Ozone seasons } \\
\text { 1995-2008 }\end{array}$ & $\begin{array}{l}40^{\circ} 16^{\prime} \mathrm{N} \\
122^{\circ} 5^{\prime} \mathrm{W}\end{array}$ & 572 & $\begin{array}{l}\text { California Air Resources } \\
\text { Board }\end{array}$ \\
\hline Red Bluff ${ }^{b}$ & $\begin{array}{l}\text { July } 1990- \\
\text { September } 2008\end{array}$ & $\begin{array}{l}40^{\circ} 11^{\prime} \mathrm{N} \\
122^{\circ} 14^{\prime} \mathrm{W}\end{array}$ & 98 & $\begin{array}{l}\text { California Air Resources } \\
\text { Board }\end{array}$ \\
\hline \multicolumn{5}{|c|}{ Other California Surface Sites } \\
\hline Trinidad Head & $\begin{array}{l}\text { April 2002- } \\
\text { December } 2008\end{array}$ & $\begin{array}{l}41^{\circ} 3^{\prime} \mathrm{N} \\
124^{\circ} 9^{\prime} \mathrm{W}\end{array}$ & 100 & NOAA GMDa \\
\hline Eureka & $\begin{array}{l}\text { January } 2007- \\
\text { December } 2008\end{array}$ & $\begin{array}{l}40^{\circ} 47^{\prime} \mathrm{N} \\
124^{\circ} 11^{\prime}\end{array}$ & 21 & $\begin{array}{l}\text { California Air Resources } \\
\text { Board }\end{array}$ \\
\hline $\begin{array}{l}\text { Lassen Volcanic } \\
\text { National Park }\end{array}$ & $\begin{array}{l}\text { October } 1987- \\
\text { November } 2008\end{array}$ & $\begin{array}{l}40^{\circ} 32^{\prime} \mathrm{N} \\
121^{\circ} 35^{\prime} \mathrm{W}\end{array}$ & 1756 & $\begin{array}{l}\text { National Park Service, } \\
\text { Air Resources Division }\end{array}$ \\
\hline Yreka & $\begin{array}{l}\text { March 1981- } \\
\text { September } 2008\end{array}$ & $\begin{array}{l}41^{\circ} 44^{\prime} \mathrm{N} \\
122^{\circ} 38^{\prime} \mathrm{W}\end{array}$ & 802 & $\begin{array}{l}\text { California Air Resources } \\
\text { Board }\end{array}$ \\
\hline
\end{tabular}

a National Oceanic and Atmospheric Administration, Earth System Research Laboratory, Global Monitoring Division

${ }^{\mathrm{b}}$ Red Bluff includes two sites: Walnut Street 1990-1995 and Oak St. 1996-present.

700 total sondes had been launched by the end of 2008; of these 212 were in summer (i.e. June, July and August). There were two 4 to 6 week periods when sondes were launched on a nearly daily schedule. The analysis reported here focuses on the summer season when the large majority of $\mathrm{O}_{3}$ exceedances occur. The hourly average $\mathrm{O}_{3}$ mixing ratios measured at the surface sites in Fig. 1 are available from several data archives. The surface $\mathrm{O}_{3}$ measurements were made using standard UV-absorption analyzers; Parrish et al. (2009) discuss the quality control of these data. Appendix A of Parrish et al. (2004) compares the sonde measurements with measurements from aircraft profiles performed directly over the sonde launch site. Excellent agreement was found with the sondes averaging $1.6 \pm 2.4 \%$ higher than the aircraft data.

\section{Systematic variation of $\mathrm{O}_{3}$ in Northern California}

Measured $\mathrm{O}_{3}$ concentrations exhibit complex temporal behavior on diurnal, synoptic and seasonal scales, as well as spatial variations in three dimensions. This variability results from a manifold of production, loss and transport processes.
In order to examine the influence of transported background $\mathrm{O}_{3}$, it is necessary to understand some of the other systematic variations. The goal of this section is to provide this needed understanding.

Figure 2 shows one month of example data from four of the Northern California surface sites, and from the four sondes launched during that period. Diurnal patterns are apparent at all surface sites, but they vary widely in magnitude, even for nearby sites. Synoptic scale (i.e. over a few days) variations are also apparent. There is marked similarity in synoptic scale patterns between the two MBL sites (upper panel) and the two NSV sites (lower panel), but no obvious synoptic scale correlation between these two pairs of sites. The following sections examine the average diurnal and seasonal cycles of $\mathrm{O}_{3}$ at Northern California sites, the vertical gradient of $\mathrm{O}_{3}$ above the Pacific Coast, and introduce a simple conceptual model upon which correlation analysis will be based. 


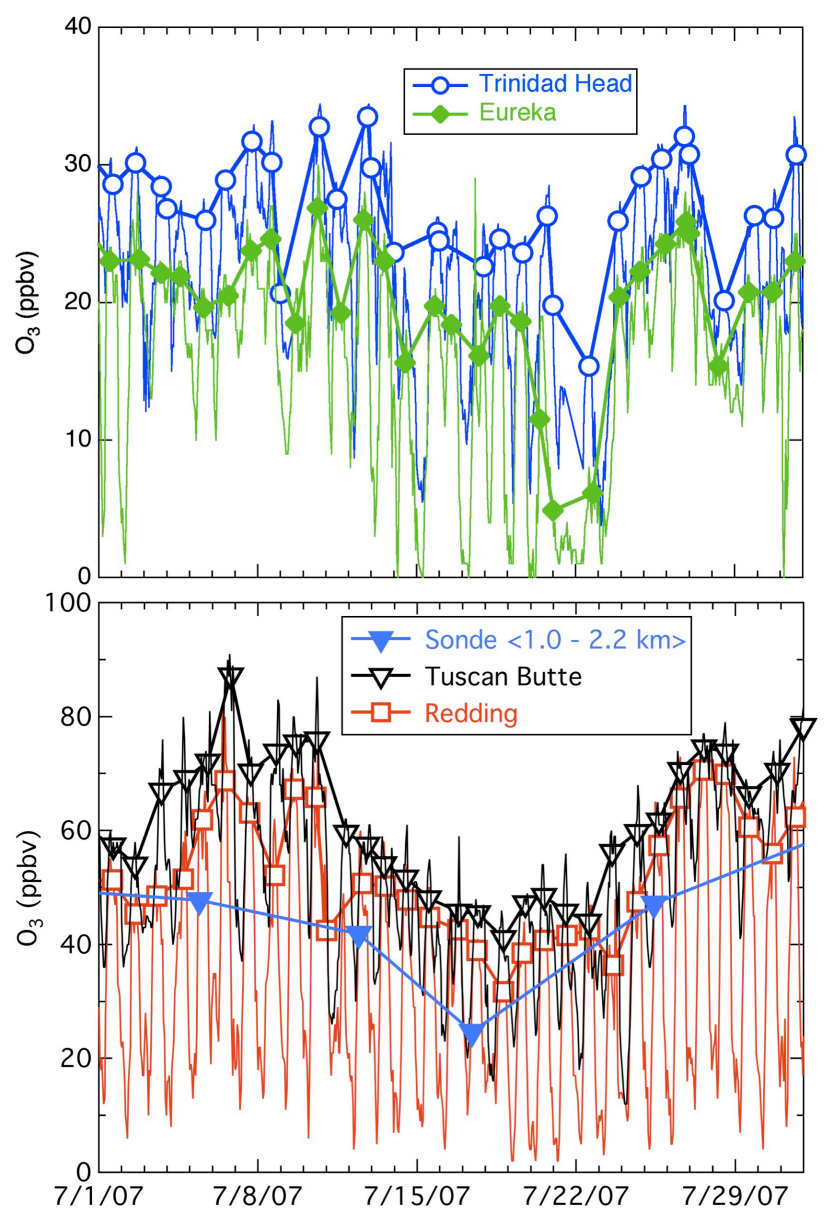

Fig. 2. One-month period of example data from four Northern California surface sites and from the sonde measurements averaged over the $1-2.2 \mathrm{~km}$ altitude range. At the surface sites the thin lines indicate hourly averaged data, and the symbols indicated the MDA8 concentrations. The heavy lines indicate linear interpolations between the symbols.

\subsection{Diurnal and seasonal cycles of surface ozone in Northern California}

The average $\mathrm{O}_{3}$ diurnal cycles in summer (June, July, August) and winter (December, January, February) at five surface sites are displayed in Fig. 3. The summertime cycles are generally typical of continental sites (e.g., Trainer et al., 1987). A daytime maximum followed by a nighttime minimum results from the interaction of the diurnal evolution of the continental boundary layer coupled with strong, local continental influences on $\mathrm{O}_{3}$. Over land the nocturnal boundary layer can be quite shallow, and $\mathrm{O}_{3}$ is depleted by deposition and reaction with species emitted at the surface. As the depth of the boundary layer grows following sunrise, higher concentrations of $\mathrm{O}_{3}$ are mixed down from layers aloft that were isolated from the boundary layer removal processes overnight. This mixing, combined with the influ- ence of daytime photochemical production of $\mathrm{O}_{3}$, leads to the well-documented afternoon $\mathrm{O}_{3}$ maximum, not only at polluted urban sites, but also at rural sites with much smaller local emissions.

In Fig. 3 in summer the four inland sites have comparably high afternoon $\mathrm{O}_{3}$ maxima, while the MBL site (Trinidad Head) exhibits a much smaller maximum. Within the MBL the land-sea breeze circulation governs the diurnal cycle. The nighttime land breeze brings continental air with relatively depleted $\mathrm{O}_{3}$ to the marine environment (for more details see Oltmans et al., 2008; Parrish et al., 2009). The two more urban sites (Redding and Yreka) exhibit the lowest nighttime minima because they receive the largest nocturnal emissions of $\mathrm{NO}_{\mathrm{x}}$, which react with and thereby remove $\mathrm{O}_{3}$, and because they are located on valley floors that have strong, shallow inversions that define the nocturnal boundary layer. In contrast, the relatively elevated locations of Tuscan Butte and Lassen NP lead to less well defined nocturnal inversions, and there are much smaller local nocturnal $\mathrm{NO}_{\mathrm{x}}$ emissions, so the nighttime minima at these sites are less pronounced.

For contrast, Fig. 3 also shows wintertime diurnal cycles. Although the $\mathrm{MBL} \mathrm{O}_{3}$ concentration is higher in winter, the two more urban sites exhibit much lower $\mathrm{O}_{3}$ due to the much shallower boundary layer throughout the day, and the relative absence of photochemical $\mathrm{O}_{3}$ production. In this season the land-sea breeze is weaker, giving a weaker MBL diurnal cycle, and the elevated Lassen NP site with little local $\mathrm{NO}_{\mathrm{x}}$ emissions exhibits little diurnal cycle.

The average seasonal cycles of $\mathrm{O}_{3}$ at five surface sites are shown in Fig. 4. These data are limited to early afternoon data (12:00-16:00 local standard time, LST) to represent the afternoon maxima of the diurnal cycles. The four inland sites all show summer maxima and winter minima, with the lowest minima found at the two more urban, valley surface sites, consistent with the lower nighttime concentrations seen even in summer at these two sites (Fig. 3). The Trinidad Head MBL site shows a very different seasonal cycle with a summertime minimum as described by Oltmans et al. (2008) and Parrish et al. (2009). Interestingly, the seasonal cycle defined by the sonde measurements above the MBL (1-2.2 km average) is more similar to that at the inland surface sites (e.g., $r=0.72$ and 0.71 at Lassen NP and Redding, respectively) than that within the MBL $(r=0.25$ at Trinidad Head).

For clarity, Figs. 3 and 4 show diurnal and seasonal cycles for only five of the Northern California surface sites. The cycles at the MBL Eureka site (see Fig. 5) are similar to those at Trinidad Head, but the $\mathrm{O}_{3}$ concentrations are significantly lower, particularly at night, due to the greater effect of $\mathrm{O}_{3}$ removal processes at its more urban location. The cycles at the other two NSV surface sites (Anderson and Red Bluff, see Fig. 1) are very similar in all respects to those illustrated for Redding. 


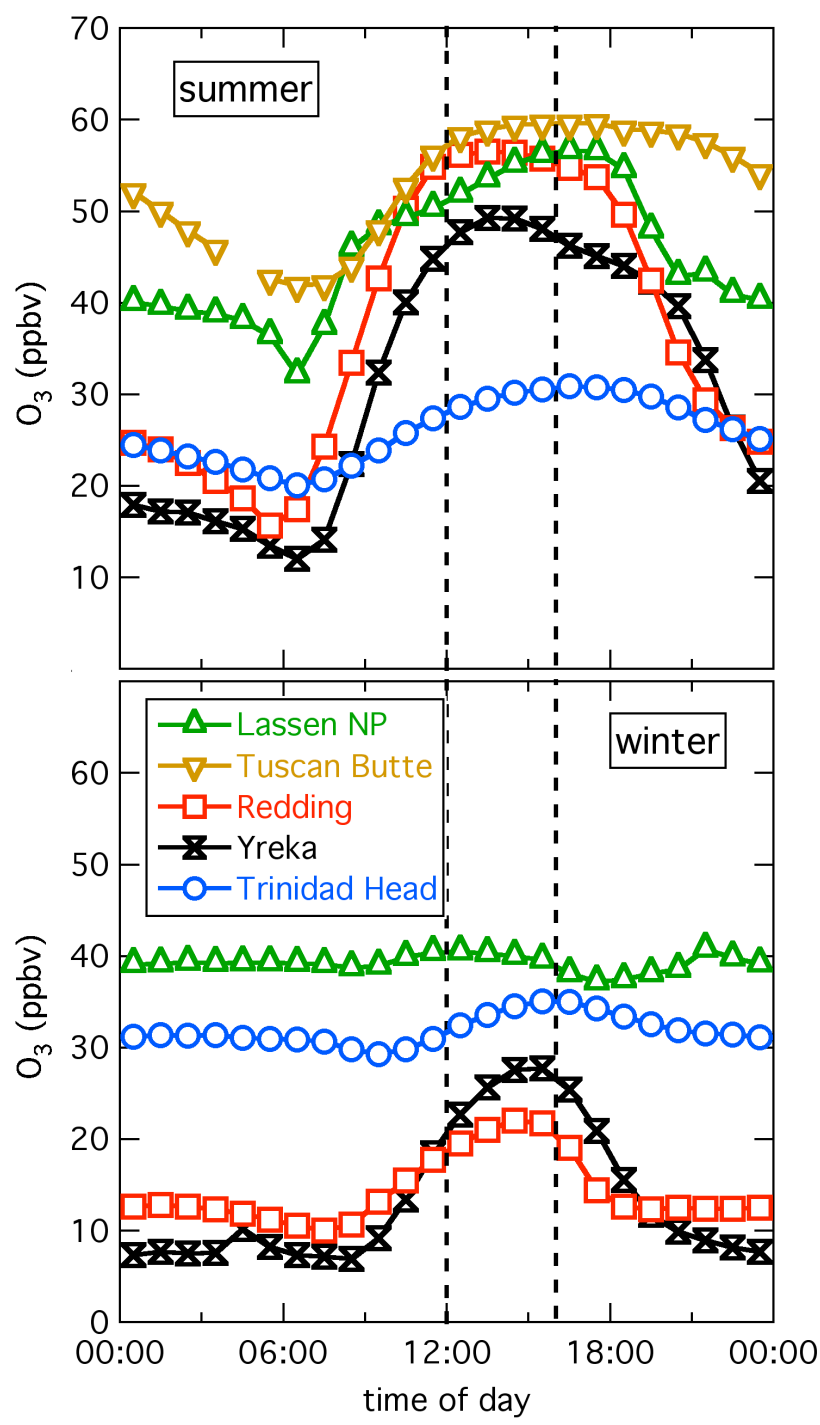

Fig. 3. Average diurnal cycle of $\mathrm{O}_{3}$ at five surface sites. All data collected in the years 2000 through 2008 are included in the surface averages. At Tuscan Butte data are unavailable in winter. The dashed lines indicate the 12:00 to 16:00 LST mid-day period included in the seasonal averages.

\subsection{Vertical gradient of marine ozone}

Characterizing the vertical distribution of $\mathrm{O}_{3}$ in onshore flow is critical to investigating the contribution that transported background $\mathrm{O}_{3}$ makes to surface concentrations in downwind continental regions. This importance arises because air from above the MBL can be mixed to the surface by a variety of transport mechanisms as marine air enters the continental environment. Figure 5 illustrates the seasonal dependence of the vertical gradient of $\mathrm{O}_{3}$ determined from ozone sondes launched at Trinidad Head and the two nearby MBL surface measurements. Surface $\mathrm{O}_{3}$ at Trinidad Head and Eureka exhibits a spring maximum and summer minimum, while at

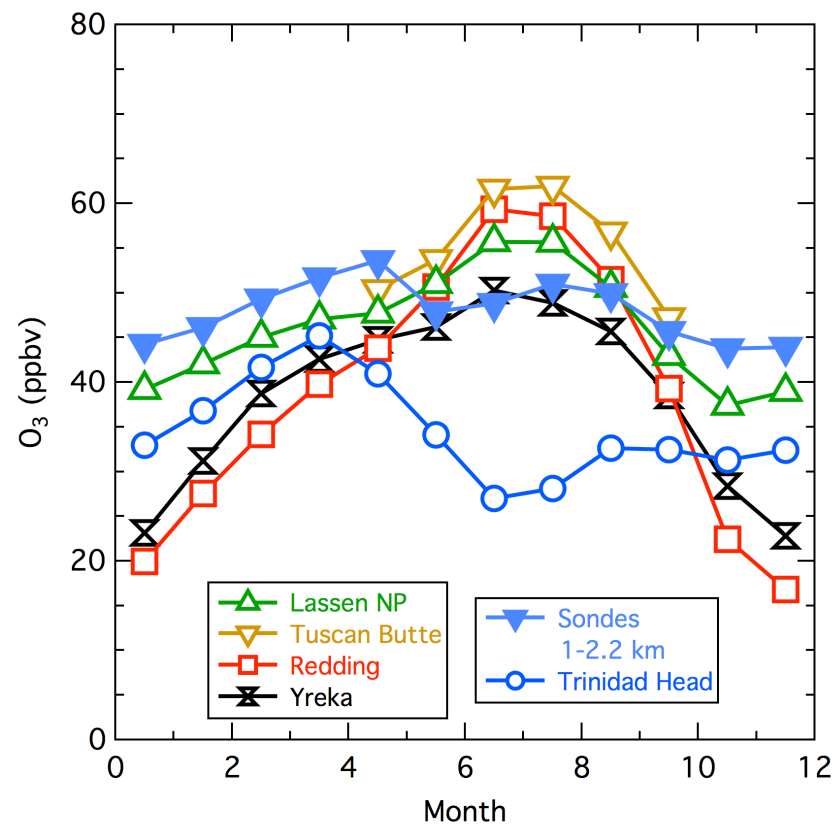

Fig. 4. Average seasonal cycle of $\mathrm{O}_{3}$ at five surface sites compared with that measured by the sondes averaged over the $1-2.2 \mathrm{~km}$ altitude range. All data collected from 12:00 to 16:00 LST for the years 2000 through 2008 are included in the surface averages. At Tuscan Butte data are available only from May through October.

altitudes of 2 to $4 \mathrm{~km}$, the seasonal cycle has a broad springsummer maximum. The wide spacing of the lower contours in summer demonstrates the very strong vertical gradient in that season for $\mathrm{O}_{3}$ between the surface and $4 \mathrm{~km}$ altitude. In summer the Trinidad $\mathrm{Head}_{3}$ mixing ratio averages $29.8 \pm 6.4 \mathrm{ppbv}$ at the surface site, and $52.7 \pm 15.8 \mathrm{ppbv}$ at $2 \mathrm{~km}$. The indicated standard deviations demonstrate that the variability has an even stronger vertical gradient than the average mixing ratio itself. The causes of this variability likely include long-range transport of pollution, a wide variation of emission and photochemical histories for the air masses approaching the California coast, and varying stratospheric influences.

The Trinidad surface data provide a good characterization of the $\mathrm{MBL} \mathrm{O}_{3}$. The site is located on an elevated peninsula directly exposed to the MBL air flow. The data included in Fig. 5 are from the midday window that is likely to be most representative of the mixed boundary layer behavior (Oltmans et al., 2008). Parrish et al. (2009) show that filtering data for high northwest winds effectively eliminates continental influences at the Trinidad Head surface site, and this window gives a summertime average of $28.9 \pm 6.8 \mathrm{ppbv}$ for the 2002-2007 period considered in that study, which compares well with the average of the data in Fig. 5. The summertime average of the Eureka data is significantly smaller $(23.1 \pm 7.1 \mathrm{ppbv})$, which reflects the loss of $\mathrm{O}_{3}$ due to deposition and reaction with continental emissions at the less 
exposed and more polluted Eureka station located in a town. The difference between these two sites demonstrates one of the difficulties of measuring marine $\mathrm{O}_{3}$ at a continental surface site.

\subsection{Conceptual model for analysis of surface ozone data}

It is well known and widely accepted that background, regional and local influences all affect measured $\mathrm{O}_{3}$ concentrations at any particular site. To clarify and guide the correlation analysis required in the following discussion, we require an explicit, quantitative statement of this concept. For this purpose we conceptually define surface $\mathrm{O}_{3}$ as the sum of three contributions,

$\mathrm{O}_{3}=\mathrm{O}_{3}$ (background) $+\mathrm{O}_{3}$ (regional) $+\mathrm{O}_{3}$ (local)

The temporal behavior of measured surface $\mathrm{O}_{3}$ illustrated in Fig. 2 dictates this formulation. For the Northern California sites considered here, we define $\mathrm{O}_{3}$ (background) as that transported to the site from the marine environment, $\mathrm{O}_{3}$ (regional) as the net contribution from processes that are relatively homogeneous over a region under consideration, and $\mathrm{O}_{3}$ (local) as perturbations due to very local influences. The first two terms in Eq. (1) are primarily responsible for the synoptic scale variability of $\mathrm{O}_{3}$, while the third term is primarily responsible for the diurnal cycles apparent in Fig. 2. In summer $\mathrm{O}_{3}$ (regional) represents the net change to the transported background $\mathrm{O}_{3}$ concentration due to regionally similar deposition and photochemical production and destruction processes. The local perturbations include local differences in photochemical production and destruction, but more importantly, $\mathrm{O}_{3}$ removal by reaction with local emissions and surface deposition, which have strong local variability. Such local effects can be quite pronounced; as shown in Fig. 2 the observed $\mathrm{O}_{3}$ can approach zero during calm nights with shallow nocturnal inversion layers at the Eureka and Redding sites. Such strong local $\mathrm{O}_{3}$ removal has much less effect at the other two sites.

It must be recognized that the conceptual model adopted here is not to be taken to indicate that we will be able to separately quantify the three terms, as each of these quantities will vary in its own characteristic manner, differently at each site, and in practice any attribution of measured $\mathrm{O}_{3}$ among the three terms would have substantial ambiguity. Equation (1) simply provides a framework for developing the correlation analysis upon which this paper is based.

We choose the maximum daily 8-h average (MDA8) mixing ratio as a measurable quantity that is most directly related to the sum of the first two terms, although the MDA8 certainly does have a significant local contribution. The following analysis will focus on these averages, which are indicated by the symbols for the respective sites in Fig. 2. We wish to investigate the relative contributions that $\mathrm{O}_{3}$ (background) and $\mathrm{O}_{3}$ (regional) make to the measured $\mathrm{O}_{3}$ concentrations in the NSV. For this purpose $\mathrm{O}_{3}$ (local) represents confounding factors. Taking the MDA8 $\mathrm{O}_{3}$ measured at a given site on a given day avoids local influences as fully as possible. The 8-h averaging period is chosen because it is the basis for the current NAAQS, and it minimizes the influence of any short-lived transient in $\mathrm{O}_{3}$. Further, these maximum averages generally occur in the early afternoon at continental surface sites, so that the MDA8 $\mathrm{O}_{3}$ is representative of the $\mathrm{O}_{3}$ concentration when the convective boundary layer is fully developed and measurements at a surface site can be expected to be more regionally representative. $\mathrm{O}_{3}$ (background) and $\mathrm{O}_{3}$ (regional) are each expected to contribute to the daily maximum $\mathrm{O}_{3}$ concentration observed at a given site. In the following analysis we consider only these MDA8 $\mathrm{O}_{3}$ values, and do not further consider $\mathrm{O}_{3}$ (local).

Since transport plays a prominent role in determining observed $\mathrm{O}_{3}$ concentrations, we must allow for time offsets in the correlation between measurements at two different locations. This allowance is accomplished by linear interpolations between the successive MDA8 values, which are indicated by the heavier lines in Fig. 2. These linearly interpolated values are taken as the best estimate of the $\mathrm{O}_{3}$ concentrations that would be observed in the absence of local effects. It is these hourly-interpolated, MDA8 values from all the surface sites that are analyzed further here. They are calculated for each hour, and are taken to approximate the hourly dependence of the sum of the first two terms of Eq. (1).

\section{Correlation analysis of measured ozone concentrations}

The analysis presented below is based upon correlations between $\mathrm{O}_{3}$ data collected at surface sites and between data from a particular surface site and the sonde measurements. Equation (1) suggests such a correlation approach. We expect the Trinidad Head sonde data from above the MBL to depend only on $\mathrm{O}_{3}$ (background) and in fact assume that the sonde data provide an effective measure of $\mathrm{O}_{3}$ (background). We further expect the surface $\mathrm{O}_{3}$ in the NSV at all of the sites to depend strongly on both $\mathrm{O}_{3}$ (background) and $\mathrm{O}_{3}$ (regional), and these dependences to be reflected in the linear correlations between data sets. To investigate the influence of transport, the correlations between $\mathrm{O}_{3}$ at two sites will be calculated as a function of the time offset between data sets; the time offset that gives maximum correlation will be taken to represent the time for transport between the measurement locations. Correlations of surface data with sonde data will be calculated as a function of sonde altitude as well as time offset between sonde and surface measurement times; the altitude that gives the best correlation with the surface data will be taken to represent the altitude from which air is preferentially transported into the NSV. The intercept and slope of the correlation between the sonde and surface data allow 


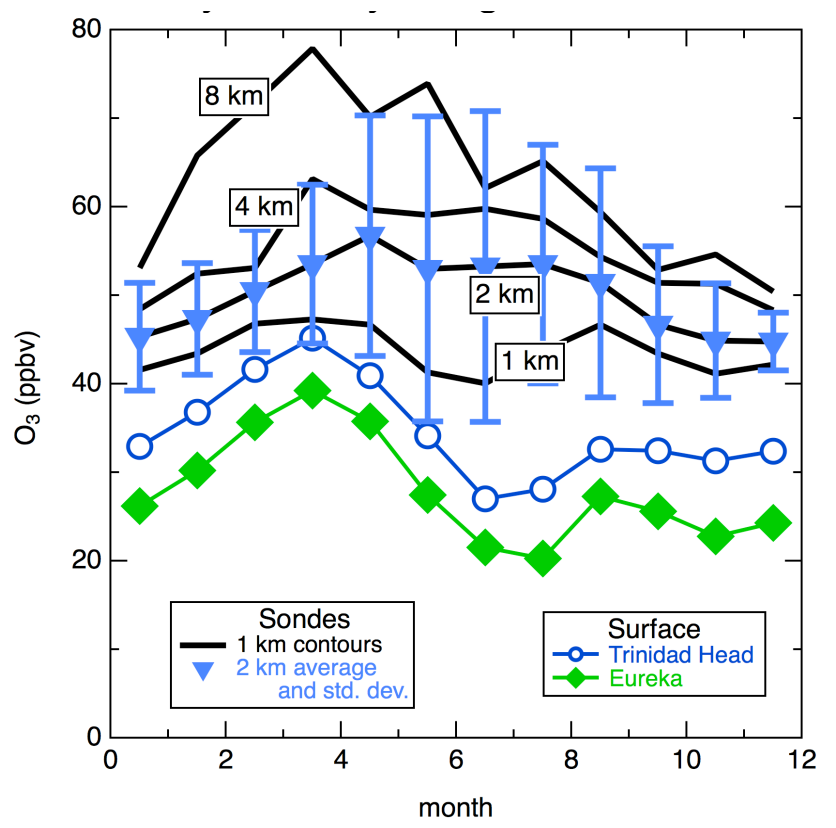

Fig. 5. Seasonal cycle of vertical $\mathrm{O}_{3}$ gradient above Trinidad Head, California. The sonde contours are monthly averages of all sonde data collected within $200 \mathrm{~m}$ of indicated altitude. For the $2 \mathrm{~km}$ contour, the error bars indicate the standard deviations of the data about the monthly averages. The monthly average data collected from 12:00 to 16:00 LST for the years 2000 through 2008 are shown for two Northern California MBL sites.

characterization of the influence of transported $\mathrm{O}_{3}$ (background) on the concentration observed at the surface site.

\subsection{Correlation of ozone at surface sites}

MDA8 $\mathrm{O}_{3}$ concentrations measured at surface sites within and near the NSV are found to correlate. Figure 6 shows two example correlations, and Table 2 compares the correlation coefficients for all pairs of surface sites. These correlations include all available coincident summertime data for the time periods listed in Table 1. The four sites within the NSV (first four lines in Table 2 in bold print) all correlate relatively strongly $(r=0.70-0.83$ ). The two MBL sites (Eureka and Trinidad Head) have the strongest correlation of any of the surface sites $(r=0.93)$, but do not correlate significantly with any of the NSV sites $(r \leq 0.08$; two lines in bold italic print in Table 2). The high elevation Lassen site correlates with the NSV sites, but not significantly with the MBL sites. The Yreka site correlates somewhat more weakly with all of the inland sites, and even more weakly with the MBL sites.

The correlations between MDA8 $\mathrm{O}_{3}$ summarized in Table 2 indicate that the sum of $\mathrm{O}_{3}$ (background) $+\mathrm{O}_{3}$ (regional) does have a strong regional character. Correlations are strong between sites in the same region, but are weak when sites are in different regions with strong topographic separation (e.g. the NSV and the MBL sites). However, since

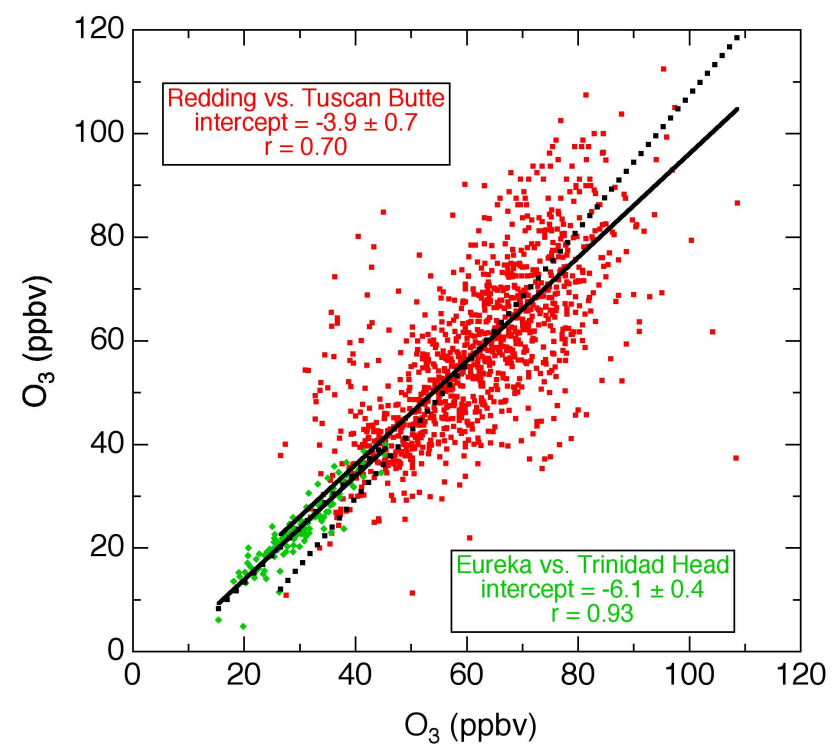

Fig. 6. Correlations between summer MDA 8 ozone for the two pairs of sites included in Fig. 2. Redding and Tuscan Butte are in the NSV; Eureka and Trinidad Head are proximate MBL sites. The solid lines indicate the linear regressions to the data sets with the slope fixed at unity. The intercept and the correlation coefficient for these fits are indicated in the respective annotations. The dotted lines indicate the standard linear regressions.

the correlations between sites in a given region are not perfect, it is clear that the MDA8 $\mathrm{O}_{3}$ does have significant local influence, but local effects do not dominate these averages. In summary, these correlations do support the use of MDA8 $\mathrm{O}_{3}$ to investigate $\mathrm{O}_{3}$ (background) $+\mathrm{O}_{3}$ (regional), but we do need to consider that these averages also are affected by local influences.

Linear regressions indicated by the solid lines in Fig. 6 were calculated with the slope fixed at unity. The intercepts of these fits give a direct measure of the offset of the data sets from each other, since they are mathematically identical to the average difference between the MDA8 $\mathrm{O}_{3}$ values at the two sites. These intercepts will be used as the measure of the average difference in $\mathrm{O}_{3}$ concentrations between data sets. The uncertainty of each intercept derived from the linear regression is equal to the uncertainty calculated for the average difference between the MDA8 $\mathrm{O}_{3}$ values of the two data sets.

The correlation between data sets collected at surface sites in the same region change as the data sets are shifted in time with respect to each other, and these shifts provide information regarding the transport of ozone within the region. Figure 7 shows that for the data sets included in Fig. 6, the correlations decrease as a time shift is introduced between the data sets. The correlation of a data set with itself (i.e. autocorrelation) decreases from a perfect correlation of unity, and correlations between two sites in the same region decrease in 
Table 2. Summertime correlation coefficients for $\mathrm{O}_{3}$ measured at different sites. MDA $8 \mathrm{O}_{3}$ concentrations are correlated between surface sites; the correlation between surface sites and the sondes are discussed in the text. Bold font denotes correlations between NSV sites, and bold-italic font denotes correlations between MBL and NSV sites. All available coincident data are included in the correlations.

\begin{tabular}{|c|c|c|c|c|c|c|c|c|c|}
\hline Correlation Coefficient & $\begin{array}{l}\stackrel{\infty}{\Xi} \\
\stackrel{D}{D} \\
\mathscr{D}\end{array}$ & 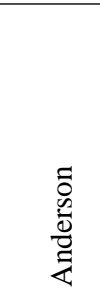 & 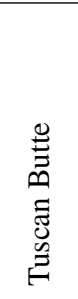 & $\frac{\mathscr{\Xi}}{\Xi}$ & 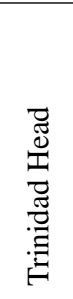 & $\underset{I}{\frac{\pi}{d}}$ & 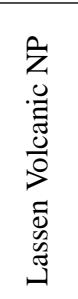 & $\frac{\widetilde{J}}{\grave{D}}$ & 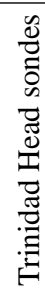 \\
\hline Redding & 1 & & & & & & & & \\
\hline Anderson & $\mathbf{0 . 8 3}$ & 1 & & & & & & & \\
\hline Tuscan Butte & 0.70 & 0.82 & 1 & & & & & & \\
\hline Red Bluff & 0.74 & $\mathbf{0 . 8 3}$ & 0.76 & 1 & & & & & \\
\hline Trinidad Head & -0.00 & -0.06 & 0.04 & 0.00 & 1 & & & & \\
\hline Eureka & 0.05 & 0.02 & 0.06 & 0.08 & 0.93 & 1 & & & \\
\hline Lassen Volcanic NP & 0.62 & 0.66 & 0.70 & 0.57 & 0.04 & 0.15 & 1 & & \\
\hline Yreka & 0.54 & 0.57 & 0.52 & 0.46 & 0.19 & 0.32 & 0.51 & 1 & \\
\hline Trinidad Head sondes & 0.43 & 0.43 & 0.51 & 0.51 & 0.43 & - & 0.61 & 0.70 & 1 \\
\hline
\end{tabular}

a similar manner. To get the best characterization of the dependence of the correlation on the time shift, even for weak correlations between statistically limited data sets, the peak of the correlation dependence is fit to a Gaussian function:

$y(t)=A \exp \left[-\left(t-t_{0}\right)^{2} / w^{2}\right]$

where $t$ is the time shift, $t_{0}$ is the offset of the maximum correlation from a zero time offset, $w$ is the width of the distribution (i.e. the time to decrease by a factor of $e$ from the maximum), and $A$ is a normalization factor. The dotted curves in Fig. 7 show the Gaussian functions fit to the respective correlations. There is some subjectivity in the selection of the width of the peak to be fit; this width is selected so that the Gaussian gives a good representation of at least the upper half of the peak.

In both the autocorrelations and the correlations between different sites in Fig. 7, the Gaussian fits decrease from their maxima with a characteristic time, $w$, of two to three days. A horizontal arrow indicates $w$ for each distribution in Fig. 7. There is good agreement between the value of $w$ determined from the autocorrelation and the inter-site correlation in the MBL and NSV regions. This characteristic time is interpreted as the average time required for synoptic scale air masses to pass through the region in which the site(s) are located; it is slightly shorter ( $w \approx 2.4$ days) in the relatively open MBL region than in the $\operatorname{NSV}(w \approx 2.7$ days), which is largely enclosed by surrounding mountains. Interestingly, the correlation coefficients do not drop to zero even for a ten day offset; this non-zero correlation is attributed to the systematic change in average ozone concentrations through the summer season (see Fig. 4).
In Fig. 7 there is little indication of a systematic offset of any of the correlation functions from zero, i.e. $t_{0} \approx 0$, although the correlation between the Redding and Tuscan Butte sites does maximize if the Redding data are offset $0.8 \pm 0.4 \mathrm{~h}$ later than the Tuscan Butte site. These offsets near zero again indicate the regional character of the $\mathrm{O}_{3}$ concentration within the NSV. There is no indication of transport from the most urban site (Redding) to the most rural site (Tuscan Butte). If significant, the small time offset indicates that transport of $\mathrm{O}_{3}$ affects the Tuscan Butte site $0.8 \mathrm{~h}$ before it affects Redding, despite the fact that the summertime daily maximum $\mathrm{O}_{3}$ occurs several hours earlier at Redding than at Tuscan Butte (see Fig. 3).

\subsection{Correlation between ozone measured by sondes and at surface sites}

MDA8 $\mathrm{O}_{3}$ concentrations measured at NSV surface sites are also found to correlate with the Trinidad Head ozone sonde measurements. These correlations add another dimension to the correlation dependence - that of the sonde altitude. Figure 8 shows the correlation between the Tuscan Butte NSV site and the average of the sonde measurements between 1 and $2.2 \mathrm{~km}$ altitude, as well as the autocorrelation of these sonde averages. This altitude range is selected for the sonde average because, as will be shown below, it is this range that correlates most strongly with the surface sites.

The correlation between the surface and sonde data maximizes when the surface data are shifted to a significantly earlier time ( $\left.t_{0}=22.4 \pm 0.6 \mathrm{~h}\right)$ with respect to the sonde data. This time delay is interpreted as the average of the total time required for the air mass sampled by the sonde to arrive above 


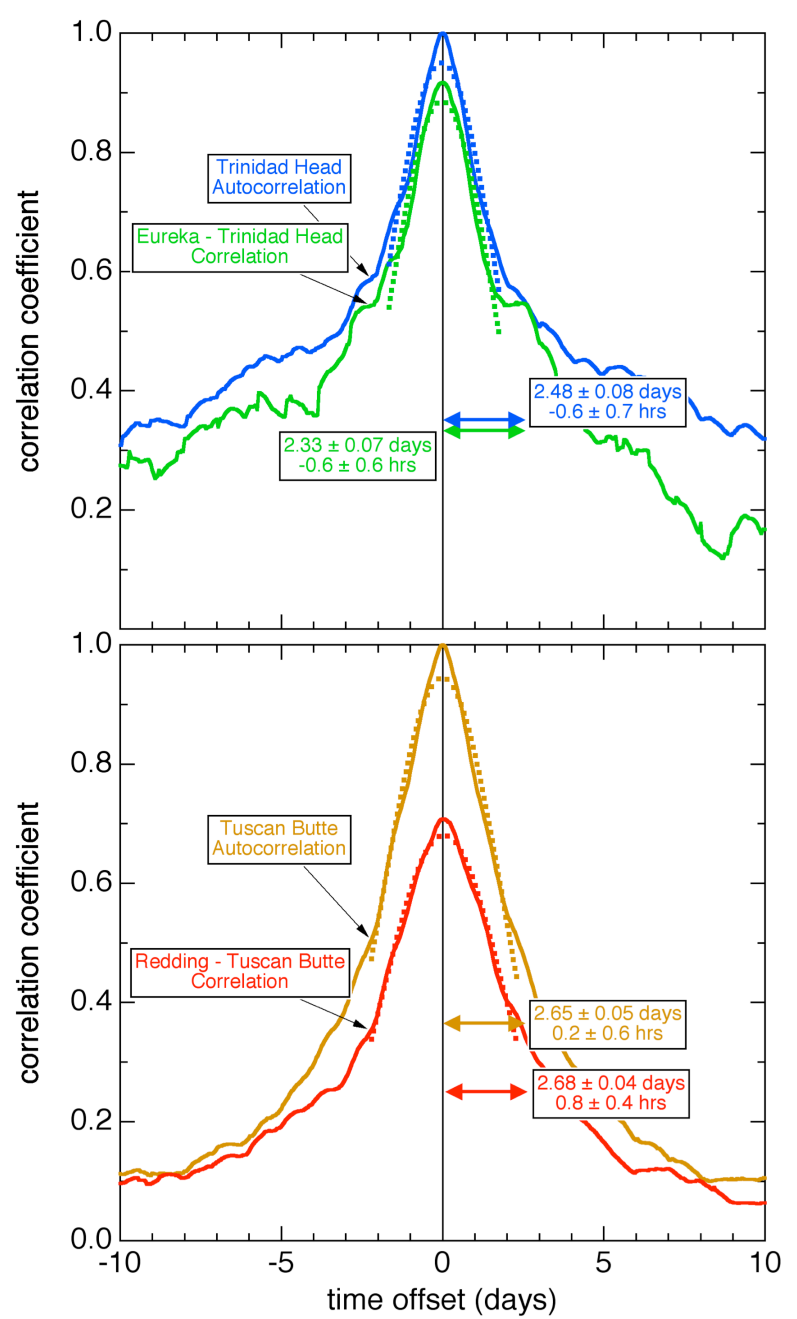

Fig. 7. Correlation coefficient between summertime interpolated MDA8 ozone at surface sites as a function of the time offset between data sets (solid lines) and Gaussian fits to the peak of the correlations (dotted lines). The correlations of data from one site with itself (autocorrelation) and between two sites are shown in each panel. The arrows indicate the width (in days) and the offset of the center of the Gaussian fits from zero time (in hours). The time offset is referenced to Trinidad Head and Tuscan Butte in the upper and lower panels, respectively.

the NSV location and for that air to mix from the 1 to $2.2 \mathrm{~km}$ altitude range to the surface. The fact that $\mathrm{O}_{3}$ concentrations in NSV lag the sonde measurements suggests that the cause of the correlation is transport of air from the sonde location to the surface of the NSV, not transport in the reverse direction. The width of the autocorrelation function of the sonde data ( $w=2.02 \pm 0.03$ days) is shorter than the autocorrelation functions at the surface sites $(w=2.48 \pm 0.08$ and $2.65 \pm 0.05$ days at the MBL and NSV sites, respectively), which is consistent with faster passage of synoptic scale air masses in the FT than at the surface.

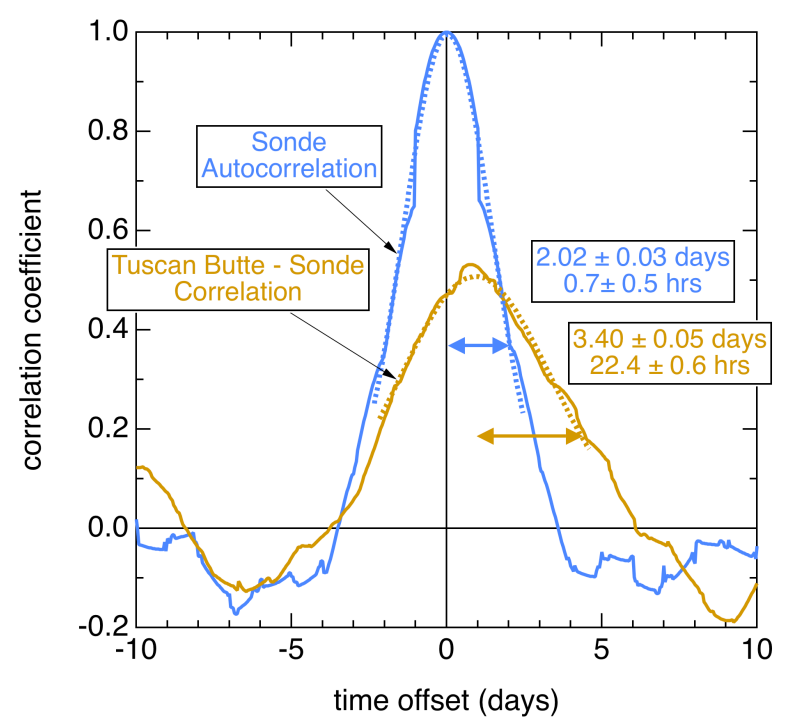

Fig. 8. Correlation analysis of sonde data averaged over the 1 to $2.2 \mathrm{~km}$ altitude range and the interpolated MDA8 ozone at the Tuscan Butte surface site during summer. The correlation coefficient of the auto correlation of the sonde data and between the sonde and the surface site are plotted as a function of the time offset between data sets (solid lines) and Gaussian fits to the peak of the correlations (dotted lines). The arrows indicate the width (in days) and the offset from zero time (in hours) of the Gaussian fits. The time offset is referenced to the sonde data.

The width of the correlation distribution for the sonde and surface measurements ( $w=3.40 \pm 0.05$ days) is significantly greater than the width of any other distribution in Figs. 7 and 8. This characteristic time is interpreted as the convolution of the distribution of times required for the air masses sampled by the sonde to pass through the region, the distribution of times required for mixing of the air from the 1 to $2.2 \mathrm{~km}$ altitude range to the surface, and the distribution of times required for flushing the valley by air transport. This width $w=3.40 \pm 0.05$ days is in excellent agreement with the rootmean-square sum (3.36 days) of 2.02 days and 2.68 days, the values of $w$ derived for the sonde and Tuscan Butte autocorrelations, respectively. This relationship is expected if the width of the sonde autocorrelation is dependent only on transport of air masses in the FT, and the width of the surface site autocorrelation is dependent only on the mixing of the air to the surface and flushing the valley by air transport. This agreement supports our concept of transport of background air into the NSV.

\subsection{Altitude dependence of correlation between sonde and surface measurements}

The correlations of the sonde data with surface measurements at five sites are investigated in Figs. 9 and 10. Two sites are those within the NSV where the highest $\mathrm{O}_{3}$ 
concentrations are observed: Tuscan Butte, the most isolated rural site, which is elevated above the valley floor, and Redding, the most urban site. Three contrasting sites are also considered: the MBL Trinidad Head site, the rural Lassen Volcanic National Park at an elevation of $1.8 \mathrm{~km}$ east of the NSV, and Yreka, a small town in a separate valley north of the NSV.

In summer surface $\mathrm{O}_{3}$ at all five sites correlates significantly with the $\mathrm{O}_{3}$ transported ashore as measured by the sondes, but with a different altitude dependence inland than at the coast (Fig. 9a). The coastal MBL Trinidad Head surface data correlate strongly with the sonde measurements from the surface to $500 \mathrm{~m}$ altitude. This correlation is expected as both measurements characterize $\mathrm{O}_{3}$ within the MBL. The correlation coefficient does not approach unity at any altitude (maximum $=0.64$ at $0.1 \mathrm{~km}$ ) because the Trinidad Head surface data represent the maximum 8-h MBL $\mathrm{O}_{3}$ averages, which typically occur in the late afternoon (see Fig. 3) when the sea breeze is fully developed, while the sondes are launched earlier in the day, generally between 09:00 and 13:00 LST. Further, they are launched on land within the small town of Trinidad Head, where deposition and reaction with local emissions reduce $\mathrm{O}_{3}$ concentrations near the surface. At all of the inland sites, the maximum correlation of the surface $\mathrm{O}_{3}$ is found for the sonde data from the 1 to $2.5 \mathrm{~km}$ altitude range. The cause of the correlation is attributed to transport of marine air from this altitude range to the inland surface sites. Importantly, the correlation drops to near zero at about $400 \mathrm{~m}$, which represents the mean top of the MBL.

In summer, the correlation of sonde data from the 1 to $2.5 \mathrm{~km}$ altitude range with the four inland surface sites maximizes 20 to $30 \mathrm{~h}$ after the sonde launch (Fig. 9b). This time offset suggests that $\mathrm{O}_{3}$ transported ashore in this altitude range on one day, most strongly affects the surface $\mathrm{O}_{3}$ on the following day. The offset is interpreted as the average time required for the transport of air from the coastal sonde station to the inland sites and mixing to the surface. It is notable that this offset generally increases with the distance between the sonde station and the respective surface site.

The $\mathrm{O}_{3}$ concentrations measured at the inland surface sites are much greater than that measured by the sondes within the MBL, but are elevated to a lesser extent ( $0-20$ ppbv) above the sonde data in the 1 to $2.5 \mathrm{~km}$ altitude range (Fig. 9c). This difference suggests that the net effect of all continental influences in the NSV and at the other surface sites results in only a modest increase of the $\mathrm{O}_{3}$ concentrations above those carried in the marine air transported ashore. In contrast, at the Trinidad Head surface site the $\mathrm{O}_{3}$ concentrations are much lower than observed at $1-2.5 \mathrm{~km}$, but elevated somewhat above that measured by the sondes in the MBL. This difference is consistent with the measured $\mathrm{O}_{3}$ diurnal cycle at Trinidad Head (Fig. 2), and the time difference between the sonde launch time and the late afternoon $\mathrm{O}_{3}$ maximum at Trinidad Head.
The correlations of the surface and sonde data are much weaker in winter than in summer (Fig. 10). The MBL sonde data correlate even more strongly with the Trinidad Head surface measurements, which reflects the much weaker land-sea breeze circulation in winter and the correspondingly reduced $\mathrm{O}_{3}$ diurnal cycle at Trinidad Head (Fig. 3). Of the inland surface sites, only the Lassen NP site exhibits a significant correlation with the sondes. At that site the maximum correlation coefficient is comparable to that found in summer, but the correlation extends to lower sonde altitudes. The delay time in the 1 to $2.5 \mathrm{~km}$ altitude range is much shorter in winter than in summer, which is interpreted as much more direct transport of marine air to the Lassen NP site in winter. The lack of correlation between the $\mathrm{O}_{3}$ measured by the sondes and that measured in NSV indicates that the valley is isolated from the FT in winter. Evidently the transport mechanism that mixes FT air to the surface in summer does not operate in winter.

\section{Transport patterns}

The correlations discussed in the previous section suggest that air is transported ashore in the 1 to $2.5 \mathrm{~km}$ altitude range and, after passing over the coastal mountain range, is mixed to the surface of the NSV. Our goal in this section is to consider if this transport is consistent with the known circulation patterns of airflow in California's Sacramento Valley.

Trajectory calculations provide a good indication of the flow patterns that bring air masses to the Pacific coast of North America. A 10-year climatology of back trajectories (Oltmans et al., 2008) indicates that a preponderance of the air parcels reaching the surface at Trinidad Head come ashore from the Pacifc Ocean. Trajectory analysis (Appendix A) shows that air sampled aloft at $2.5 \mathrm{~km}$ altitude by the sondes generally flows ashore from the Pacific and is transported eastward over North America, but that there is large variability about this general pattern. There is certainly no direct, consistent transport of air from above Trinidad Head to the NSV. However, direct transport is not required. Liu et al. (2009) show that the horizontal distance for the correlation coefficient between sonde measurements at the same altitude to decrease by a factor of $e$ is about $500-1000 \mathrm{~km}$ in the FT. Hence, the Trinidad Head ozone sonde measurements are horizontally representative of large regions, and direct transport to the NSV is not required to explain the observed correlations.

The available trajectory calculations cannot be expected to describe the details of the transport of air into the NSV. The trajectory analyses are based upon relatively coarse grid meteorological data, which can reproduce large-scale flow patterns, but not smaller scale features. This limitation is particularly relevant to the Northern California region due to large topographical gradients and large land-sea temperature differences. These features cannot be resolved in the coarse 


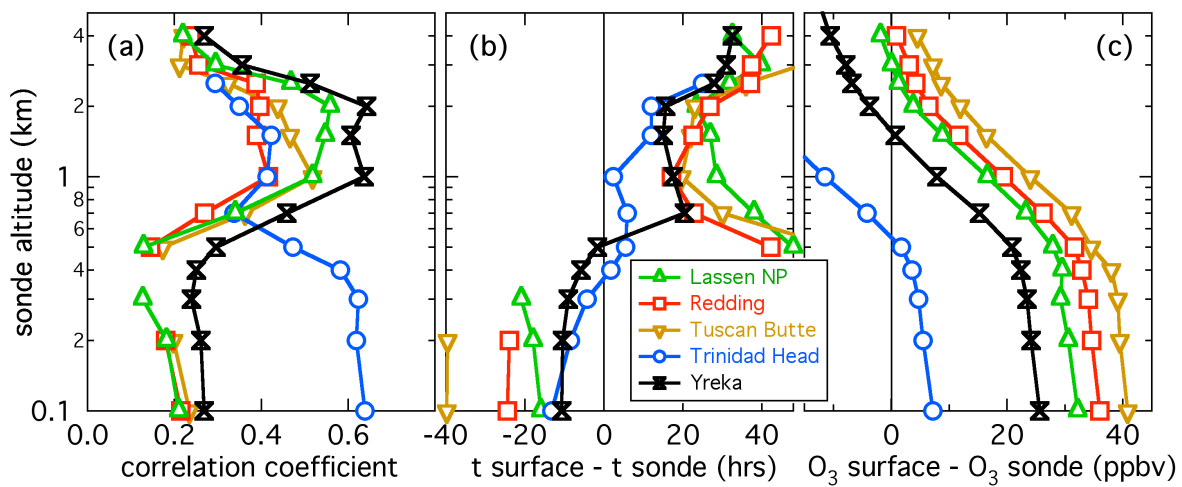

Fig. 9. Summertime results of correlation analysis between sonde data averaged over $0.1 \mathrm{~km}$ altitude range, and interpolated MDA8 ozone at surface sites as a function of sonde altitude. (a) Maximum correlation coefficient found between data sets as the time offset between data sets is varied; this maximum is taken from the Gaussian fit as exemplified in Figs. 7 and 8. (b) The time offset in hours at which the correlation coefficients in a) reached the maxima. (c) The intercept of the linear regressions to the data sets for the time offsets in a) with the slope fixed at unity (see Fig. 6 for illustration.) Data points are missing in (a) and (b) when no significant correlation was found.

grid meteorological data. It is these smaller scale transport patterns in the coastal-Sacramento valley region that we believe provide the physical cause of the correlations discussed above.

A plausible, highly simplified daytime mechanism for transporting air aloft to the valley floor is schematically illustrated in Fig. 11. As onshore flow from the Pacific encounters the complex topography of Northern California with the associated thermal gradients, important mesoscale flow patterns develop. Surface heating drives complex mountainvalley flows that can transport air through depths on the order of the terrain height (see, e.g. Dillon et al., 2002; Murphy et al., 2006). These patterns are not well documented, but they evidently determine the transport and mixing of air to the surface sites located within the convective boundary layer (CBL) in the NSV. Daytime heating of mountain slopes drives a mountain-valley flow pattern with daytime upslope flow occurring on both sides of the NSV. This mountainvalley flow exhausts air from the CBL, which is replaced by marine air transported ashore aloft subsiding into the CBL. The correlation analysis indicates that the primary inflow of air to the NSV descends from altitudes of 1 to $2.5 \mathrm{~km}$. Myrup et al. (1983), using an observationally based approach, estimate that the summertime rate of subsidence in the Sacramento area is on the order of $5 \mathrm{~cm} \mathrm{~s}^{-1}$ at $1.5 \mathrm{~km}$ altitude during the daytime hours. This subsidence rate is adequate to ventilate a $1000 \mathrm{~m}$ thick PBL in less than $6 \mathrm{~h}$. During the night the circulation is largely reversed with down slope mountain flow transporting marine air into the nocturnal boundary layer. The disappearance of the correlation between the sondes and the NSV surface sites in the winter (Fig. 10) is evidence that the strong surface heating of summertime is required for the vertical mixing down of the air transported aloft over the NSV.
Figure 11 is highly simplified, as the actual flow has significant up and down valley flow components. The general surface air flow pattern in the Central Valley is westerly flow at the coast, which enters the valley at the Carquinez Strait and then splits northward and southward into the Sacramento and San Joaquin Valleys. However, this surface flow provides little overall transport into the NSV. The mean wind hodographs presented by Zhong et al. (2004) for Redding show that the flow reverses at night. The result is simply back and forth flow, which over $24 \mathrm{~h}$ yields very little net horizontal transport. Thus, the vertical motion, as schematically indicated in Fig. 11, may be responsible for ventilating the NSV. However, it should be noted that nocturnal low-level jets can move substantial amounts of air above the nocturnal boundary layer, which would complicate the simple picture of Fig. 11.

\section{Approximate ozone budget analysis}

Some aspects of the $\mathrm{O}_{3}$ budget conceptualized in Eq. (1) can be partially quantified from the correlations of $\mathrm{O}_{3}$ measured at NSV sites with $\mathrm{O}_{3}$ measured by the sondes launched at Trinidad Head. Figure 12 illustrates the correlations of the MDA8 $\mathrm{O}_{3}$ measured at Tuscan Butte (the NSV site with the highest $\mathrm{O}_{3}$ design value) and at Redding (the most urban NSV site with the second highest $\mathrm{O}_{3}$ design value) with the average $\mathrm{O}_{3}$ measured $22 \mathrm{~h}$ earlier in the 1 to $2.2 \mathrm{~km}$ altitude range by the sondes launched at Trinidad Head. Assuming that $\mathrm{O}_{3}$ (regional) and $\mathrm{O}_{3}$ (local) are independent of $\mathrm{O}_{3}$ (background) and assuming that all of the air entering the NSV descends from the 1 to $2.2 \mathrm{~km}$ altitude range, Eq. (1) implies a linear relationship with unit slope (blue lines) between the transported background $\mathrm{O}_{3}$ measured by the sonde and $\mathrm{O}_{3}$ measured at the surface site. The bivariate fits to the 


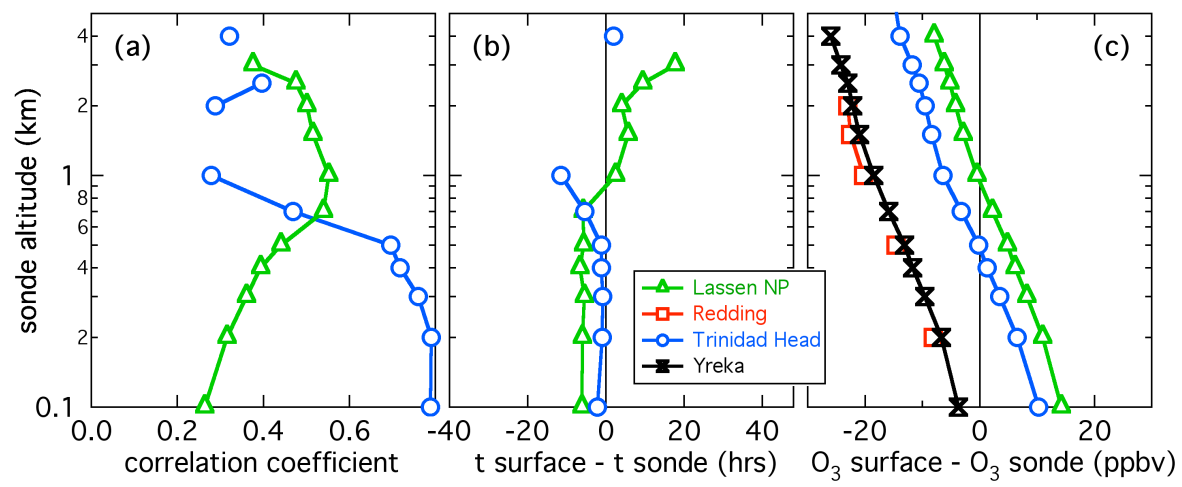

Fig. 10. Wintertime results of correlation analysis between sonde data and interpolated MDA 8 ozone at surface sites as a function of sonde altitude in the same format as in Fig. 9. In (a) and (b) data are only shown for sites with a significant correlation.

Table 3. Comparison of parameters $\pm 95 \%$ confidence limits for correlation of MDA 8 surface ozone with sonde data averaged between 1 and $2.2 \mathrm{~km}$. The delay time of the surface data with respect to the sonde launch time gives the maximum correlation coefficient, $r$, for the respective sites. The bivariate linear regression is described in the text.

\begin{tabular}{lrrrrr}
\hline Site & $\begin{array}{r}\text { Delay } \\
\text { time (h) }\end{array}$ & $\begin{array}{r}\text { Slope } \\
\text { bivariate }\end{array}$ & $\begin{array}{r}\text { Slope } \\
\text { standard }\end{array}$ & $\begin{array}{r}\text { Intercept } \\
\text { slope }=1\end{array}$ & $r$ \\
\hline Redding & 22 & $1.10 \pm 0.39$ & $0.44 \pm 0.13$ & $11 \pm 2$ & 0.42 \\
Anderson & 20 & $0.95 \pm 0.34$ & $0.41 \pm 0.13$ & $11 \pm 2$ & 0.42 \\
Tuscan Butte & 22 & $0.91 \pm 0.23$ & $0.50 \pm 0.11$ & $16 \pm 2$ & 0.53 \\
Red Bluff & 14 & $0.78 \pm 0.20$ & $0.46 \pm 0.10$ & $8 \pm 2$ & 0.53 \\
Lassen NP & 23 & $0.76 \pm 0.15$ & $0.51 \pm 0.09$ & $8 \pm 2$ & 0.60 \\
Yreka & 16 & $0.65 \pm 0.10$ & $0.52 \pm 0.07$ & $0 \pm 2$ & 0.70 \\
\hline
\end{tabular}

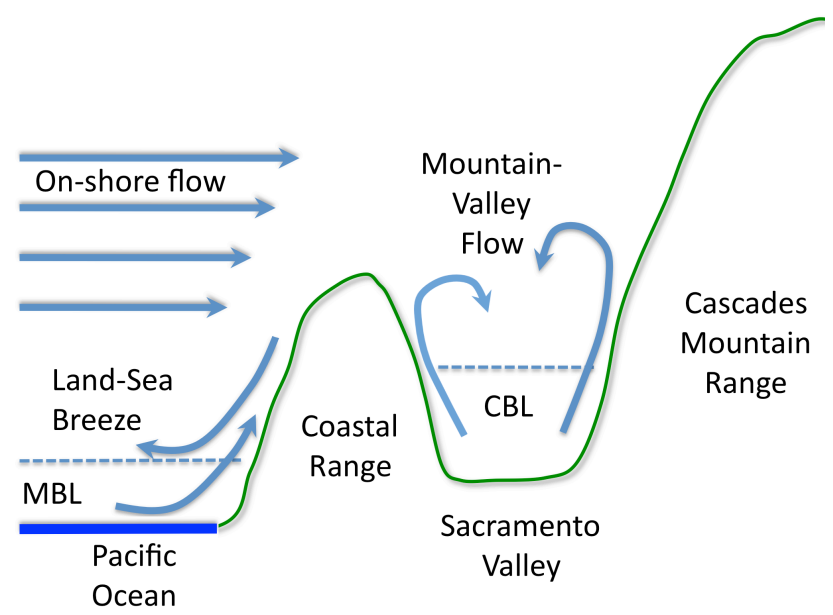

Fig. 11. Schematic diagram of east-west cross-section of Northern California topography with proposed transport mechanisms associated mid-afternoon air flow patterns. MBL and CBL represent marine boundary layer and convective boundary layer, respectively.

data (gold lines in Fig. 12) are in accord with this implication. (The bivariate fit refers a regression that allows for uncertainties in both the $x$ and $y$ variables (Neri et al., 1989; Press et al., 1992); here all $x$ and $y$ data are weighted equally.) The $y$ intercept of the blue line provides an estimate of the average of the sum $\mathrm{O}_{3}$ (regional) $+\mathrm{O}_{3}$ (local) at the respective site, which represents the average net contribution of regional and local processes to the observed MDA8 $\mathrm{O}_{3}$.

Similar results are found for all four sites in the NSV (Table 3). The slopes derived form bivariate fits are statistically equivalent or close to unity. The weighted average slope for the four sites is $0.88 \pm 0.13$, which gives the best estimate for the fraction of the air transported into the NSV that descends from the 1 to $2.2 \mathrm{~km}$ altitude range. This implies a best estimate of $0.12 \pm 0.13$ as the fraction of air transported into the NSV through other routes, such as low level flow through San Francisco Bay, the Carquinez Strait and into the Sacramento Valley. In summary, on an average summer day, the $\mathrm{O}_{3}$ (background) estimated from the sonde data equals $49 \mathrm{ppbv}$, which corresponds to 75 to $86 \%$ of the average MDA8 $\mathrm{O}_{3}$ of 57 to $65 \mathrm{ppbv}$ observed at the four NSV sites. Regional and local processes, including net photochemical production and surface deposition, contribute an average of only 8 to $16 \mathrm{ppbv}$ at the four sites. It is interesting to note that the largest net regional plus local contribution occurs at the most rural site (Tuscan Butte), not because the average peak $\mathrm{O}_{3}$ is much higher (see Fig. 3), but rather because $\mathrm{O}_{3}$ 

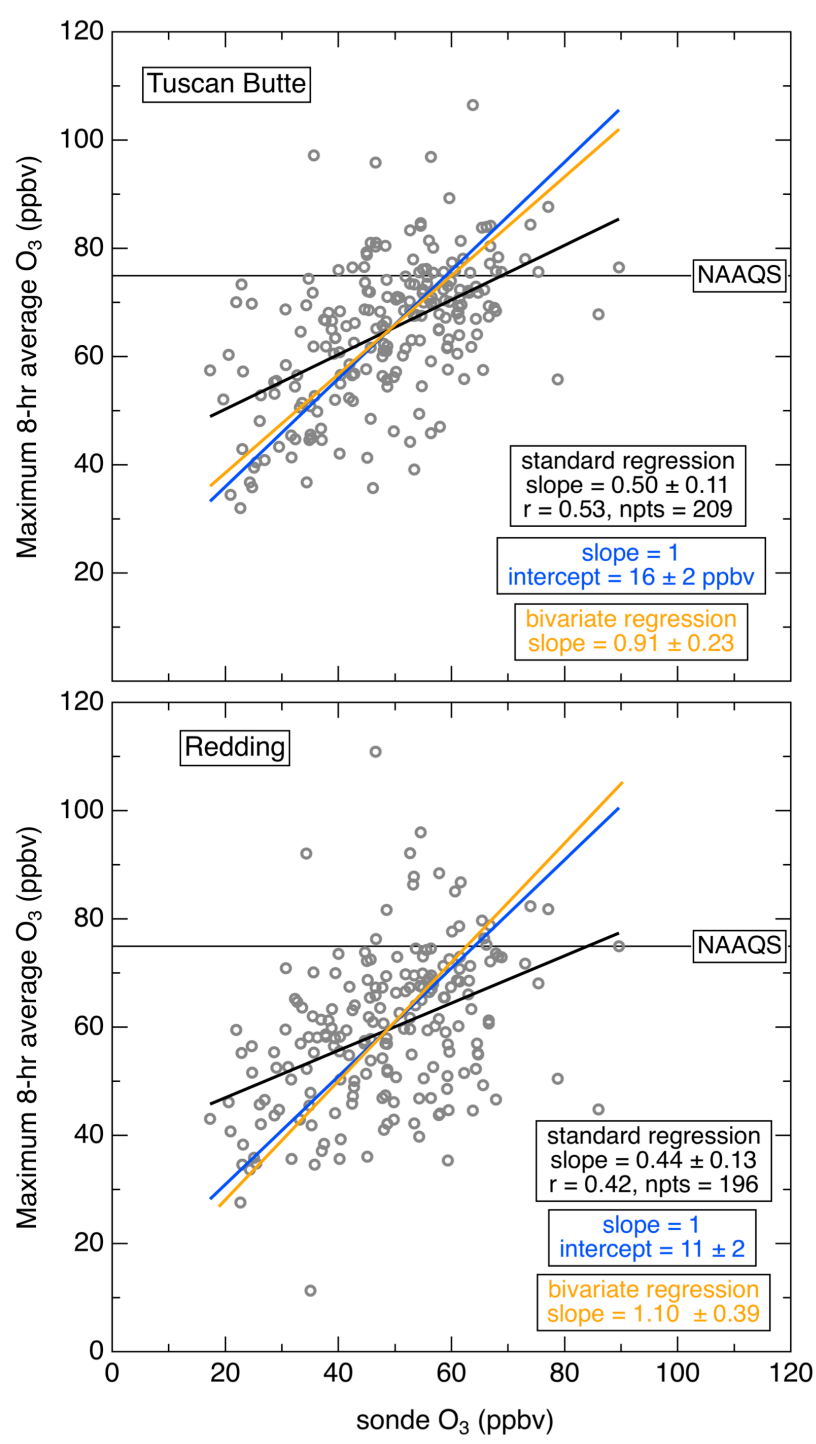

Fig. 12. Correlation between the summertime interpolated MDA8 concentrations at Tuscan Butte and Redding with the $\mathrm{O}_{3}$ mixing ratio measured by sondes $22 \mathrm{~h}$ earlier at Trinidad Head. The sonde mixing ratios are averaged over altitudes from 1.0 to $2.2 \mathrm{~km}$. The solid lines show the results of three different linear, least-squares regressions to the data: slope held at unity (blue), bivariate regression (see text) with equal weighting (gold), and a standard regression (black).

remains near the peak longer, evidently due to a lesser influence of removal processes at the rural, elevated terrain where that site is located.

The contribution of background $\mathrm{O}_{3}$ during exceedance conditions is of more importance to air quality control concerns than are the average contributions discussed in the preceding paragraph. On $21 \%$ of the summer days following sonde launches (on $18 \%$ of all summer days), the maximum MDA $8 \mathrm{O}_{3}$ recorded at Tuscan Butte exceeded the $75 \mathrm{ppbv}$ NAAQS. The average MDA8 $\mathrm{O}_{3}$ on those days was $81 \mathrm{ppbv}$ and the average background $\mathrm{O}_{3}$ was 59 ppbv (i.e. $73 \%$ of the total). The estimated $\mathrm{O}_{3}$ (regional) $+\mathrm{O}_{3}$ (local) therefore averaged $22 \mathrm{ppbv}$, and was as high as 63 ppbv. $\mathrm{O}_{3}$ (background) was always at least $34 \mathrm{ppbv}$ on exceedance days, and reached a maximum of 90 ppbv. Thus, transported background $\mathrm{O}_{3}$ alone may exceed the 75 ppbv NAAQS. On nonexceedance days (when $\mathrm{MDA} 8 \mathrm{O}_{3}$ recorded at Tuscan Butte did not exceed $75 \mathrm{ppbv}$ ) the average $\mathrm{MDA} 8 \mathrm{O}_{3}$ was $61 \mathrm{ppbv}$ and the transported background $\mathrm{O}_{3}$ averaged $48 \mathrm{ppbv}$, so $\mathrm{O}_{3}$ (regional) $+\mathrm{O}_{3}$ (local) averaged 13 ppbv. In summary, of the 20 ppbv $\mathrm{O}_{3}$ difference between an average exceedance day and an average non-exceedance day, higher transported background $\mathrm{O}_{3}$ accounts for half or more of the difference (11 ppbv), while greater net photochemical $\mathrm{O}_{3}$ production accounts for the other 9 ppbv of the difference. Comparable results are found for all NSV sites (Table 4).

One aspect of this analysis must be clearly appreciated. The sondes provide a measure of the background $\mathrm{O}_{3}$ carried by the onshore flow, and the correlations indicate that this onshore flow directly impacts the surface of the NSV. However, we have no measure of the $\mathrm{O}_{3}$ concentrations that would exist within the valley in the absence of anthropogenic emissions, i.e. the policy relevant background $\mathrm{O}_{3}$. In the absence of anthropogenic emissions the transported background $\mathrm{O}_{3}$ measured by the sondes would be reduced by photochemical destruction and surface deposition and enhanced by photochemical production from naturally emitted precursors. Detailed model calculations capable of reproducing the correlations reported here are required to accurately calculate the policy relevant background $\mathrm{O}_{3}$ concentration.

\section{Discussion and conclusions}

The arguments in this paper are based primarily upon correlations. Correlations can provide indications of the underlying cause, but cannot prove the cause. To our knowledge, there are no meteorological data available that allow a direct investigation of the cause of the observed correlations. Thus, we adopt the strategy of considering all causes that we can conceive, discarding those that are inconsistent with observations, and retaining the simplest one that remains. Five observations are particularly useful in this process. First, the correlations show that observed ozone at the NSV surface sites correlate best with the sonde observations after a time delay on the order of one day; thus whatever causes the correlation affects $\mathrm{O}_{3}$ above the MBL at Trinidad Head before it affects $\mathrm{O}_{3}$ at the surface of NSV. Second, similar $\mathrm{O}_{3}$ correlations are found between the sondes at boh Yreka and the NSV sites. Since Yreka is located in a separate valley isolated from the $\mathrm{NSV}$, the cause of the correlation cannot be confined to the NSV. Third, there is no evidence of transport of North American influenced air to altitudes above the MBL at Trinidad Head (see discussion in the Appendix). Fourth, the relatively high correlations are associated with a relatively narrow (1- 
Table 4. Comparison of average \pm standard deviation of sonde and MDA8 surface ozone between exceedance days (MDA8 ozone greater than 75 ppbv) and non-exceedance days.

\begin{tabular}{llllll}
\hline & \multicolumn{3}{c}{ Exceedance Days } & \multicolumn{2}{c}{ Non-exceedance Days } \\
Site & \% of days & Surface & Sonde & Surface & Sonde \\
\hline Redding & $\mathbf{9 . 7}$ & $85.0 \pm 8.7$ & $58.2 \pm 10.3$ & $56.7 \pm 9.6$ & $47.5 \pm 13.6$ \\
Anderson & 11.5 & $81.6 \pm 6.0$ & $58.2 \pm 12.2$ & $57.1 \pm 11.2$ & $47.6 \pm 13.3$ \\
Tuscan Butte & 20.6 & $81.3 \pm 6.9$ & $58.3 \pm 11.9$ & $60.7 \pm 11.9$ & $46.5 \pm 13.2$ \\
Red Bluff & $\mathbf{4 . 9}$ & $82.0 \pm 8.4$ & $55.2 \pm 9.0$ & $55.6 \pm 10.7$ & $48.5 \pm 13.8$ \\
Lassen NP & $\mathbf{2 . 9}$ & $82.1 \pm 4.8$ & $59.6 \pm 10.5$ & $59.6 \pm 10.5$ & $48.7 \pm 13.6$ \\
Yreka & $\mathbf{0 . 0}$ & - & - & $48.8 \pm 10.2$ & $48.7 \pm 13.9$ \\
\hline
\end{tabular}

$2.5 \mathrm{~km}$ ) altitude range over Trinidad Head. Fifth, the correlations of ozone concentrations between sonde measurements at Trinidad Head and the surface sites on the NSV floor are highest in summer, much poorer in spring and autumn and disappear in winter.

The presence of a time delay in the maximum correlation between $\mathrm{O}_{3}$ concentration above Trinidad Head and at sites in the NSV implies that some transport process is involved, and the sign of the time delay indicates that the transport process moves air form above Trinidad Head toward the NSV and Yreka sites. Since continentally influenced air is not generally transported to altitudes above the MBL at Trinidad Head, the causative process must involve transport of marine air. Figure 11 illustrates a likely mechanism for this transport that is consistent with all of the observations; it is this hypothesized cause that we have accepted, i.e. down mixing of air transported over the Coastal Range. Importantly, the $\mathrm{O}_{3}$ in this air that impacts air quality in the NSV was transported ashore from the Pacific, and was not produced over North America. Detailed transport modeling is required to more firmly establish this cause; such modeling is planned as part of the analysis of the recently completed CalNex 2010 field study (see http://esrl.noaa.gov/csd/calnex/ for more details).

Other possible causes can be proposed. One that we cannot unambiguously exclude is that transport conditions which bring particularly high $\mathrm{O}_{3}$ concentrations to the 1$2.5 \mathrm{~km}$ altitude range above Trinidad Head are somehow associated with meteorological conditions that one day later are particularly favorable for photochemical production of $\mathrm{O}_{3}$ within the NSV and the valley to the north where Yreka is located. However, this mechanism is rather complex and highly speculative without an apparent driving mechanism, and cannot explain why this process is confined to only the $1-2.5 \mathrm{~km}$ altitude range. In summary, the cause assignment we have accepted is quite likely correct.

The correlation coefficients shown in Figs. 9 and 12 are not particularly large, but strong correlations cannot be expected for two reasons. First, the correlations of the $\mathrm{MDA}_{8} \mathrm{O}_{3}$ concentrations between sites in the NSV are themselves not perfect. For example, $r=0.70$ for Tuscan Butte and Redding. The square of the correlation coefficient, $r^{2}$, can be taken as an estimate of the fraction of the variance of a dependent variable that can be explained by its dependence on an independent variable. Thus, only about half of the variance of $\mathrm{O}_{3}$ at either site can be explained by influences common to both sites. These common influences are represented by the sum $\mathrm{O}_{3}$ (background) $+\mathrm{O}_{3}$ (regional) in Eq. (1). The strongest correlations between the sondes and the surface MDA8 $\mathrm{O}_{3}$ are about $r=0.50$, which indicates that $\mathrm{O}_{3}$ (background), as measured by the sondes, accounts for approximately $25 \%$ of the total variance, which corresponds to about one-half of the variance due to $\mathrm{O}_{3}$ (background) $+\mathrm{O}_{3}$ (regional). The fact that the sonde data can capture approximately one-half of the variance caused by these two terms, and that they can capture approximately that fraction of the variance for all six inland surface sites is remarkable. A second reason that strong correlations cannot be expected is that a sonde measures $\mathrm{O}_{3}$ at one particular time and altitude above Trinidad Head, while the corresponding surface $\mathrm{O}_{3}$ is interpolated between two successive MDA8 values. The six surface sites are located 150 to $240 \mathrm{~km}$ inland from the sonde launch site in directions varying from southeast to northeast at elevations of $100 \mathrm{~m}$ to $1.8 \mathrm{~km}$; thus there must be significant horizontal and vertical variations in the $\mathrm{O}_{3}$ transported to these sites. As illustrated in the trajectory analysis presented in the Appendix, there is a great deal of variability in the transport direction. Transport times from the sonde location to the various surface sites certainly vary with meteorological conditions, while the correlation at each site assumes a single offset time. The vertical range of the air mixed to the surface must also vary with meteorological conditions. Given all of these factors contributing to variability between the sonde and the surface $\mathrm{O}_{3}$, the magnitude of the correlation coefficients are remarkably large.

The present work has several important implications:

- Effective air quality control policies aimed at achieving NAAQS compliance for $\mathrm{O}_{3}$, at least in this North Sacramento Valley region, must recognize the large background contribution identified here. This work shows that $\mathrm{O}_{3}$ air quality can be substantially impacted by an important, hemisphere-wide background component to 
which all Northern Hemisphere mid-latitude precursor emissions contribute. Policies will be more effective if they consider international efforts aimed at reducing the transported background in addition to efforts aimed at reducing local and regional precursor emissions.

- Fully characterizing California $\mathrm{O}_{3}$ concentrations through modeling studies is a daunting task. A global chemical-transport model capable of accurately reproducing the transported background $\mathrm{O}_{3}$, including its vertical, spatial and temporal variations, must be coupled with a fine resolution model that can reproduce mesoscale land-sea breeze and mountain-valley circulation patterns in complex topography with large temperature gradients. This second requirement is necessary to accurately characterize the transport of relatively $\mathrm{O}_{3}$-rich air from the lower FT into the CBL. It has not been established that current models can meet either requirement, although Huang et al. (2010) present model calculations that capture some of the features of this transport.

- Coastal air basins (e.g. Los Angeles and San Diego in California) are open to direct inflow of air from the MBL. This air will have significantly lower background $\mathrm{O}_{3}$ concentrations compared to the background $\mathrm{O}_{3}$ concentrations carried by the air that descends into the NSV. Consequently coastal air basins are expected to have a significantly higher tolerance for locally produced $\mathrm{O}_{3}$ and $\mathrm{O}_{3}$ exceedance events are expected to be significantly more responsive to local and regional control efforts compared to the NSV

- It is important to consider background $\mathrm{O}_{3}$ transported aloft, not just within the boundary layer, when evaluating its impact in regions of varying topography. Downward mixing of high background $\mathrm{O}_{3}$ concentrations is likely important in other regions in the western US. Examples include the San Joaquin Valley (the southern portion of California's Central Valley) and the Denver metropolitan area on the eastern slope of the Rocky Mountains.

\section{Appendix A}

\section{Atmospheric transport at North American West Coast}

\section{A1 Large-scale flow}

It is widely recognized that at northern mid-latitudes the zonal prevailing winds are westerly. However, there is substantial variability about this prevailing direction, especially during summertime. To obtain an approximate, large-scale

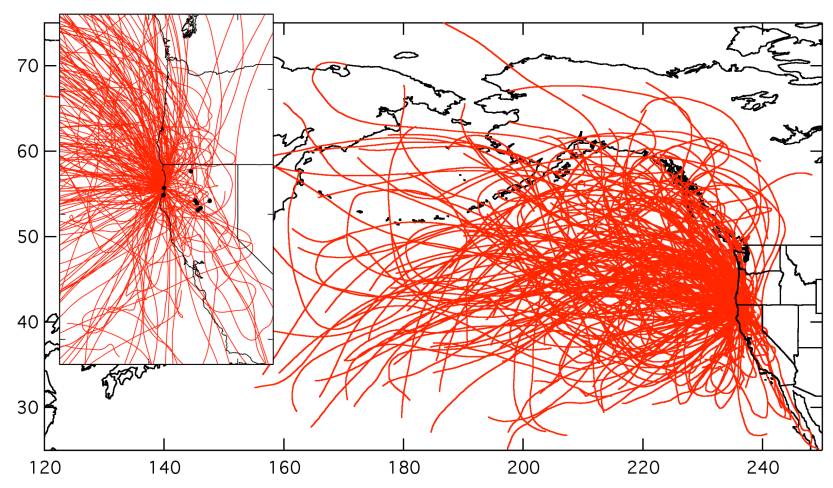

Fig. A1. Map of 5-day HYSPLIT back trajectories calculated from an altitude of $2.5 \mathrm{~km}$ a.s.1. above Trinidad Head beginning at the time of each summertime sonde launch. The inset shows more local detail around the sonde launch site; the black dots indicate the site locations given in Fig. 1.

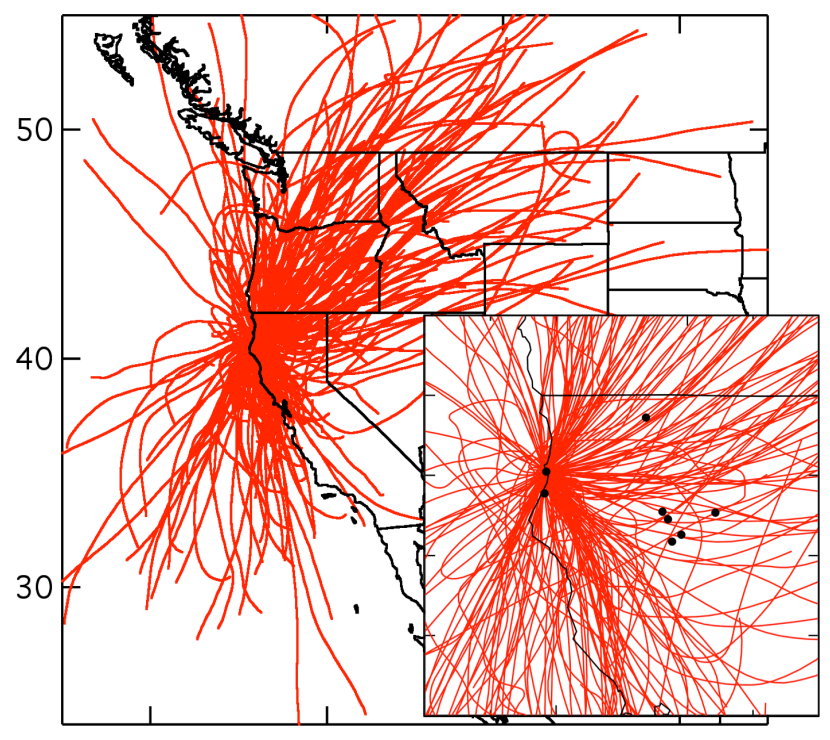
$-130$
$-120$
$-110$
$-100$

Fig. A2. Map of 2-day HYSPLIT forward trajectories calculated from an altitude of $2.5 \mathrm{~km}$ a.s.l above Trinidad Head beginning at the time of each summertime sonde launch. The inset shows more local detail around the sonde launch site; the black dots indicate the site locations given in Fig. 1.

flow picture of the actual transport of the air masses sampled by the Trinidad $\mathrm{Head}_{3}$ sondes, both back and forward trajectories were calculated (Draxler and Rolph, 2003; Rolph, 2003) beginning at $2.5 \mathrm{~km}$ altitude above Trinidad Head and at the time of the sonde launch (Figs. A1 and A2). These figures clearly show both the generally westerly flow, and the large variability that any particular trajectory can follow. Overall, the trajectories indicate that the air above Trinidad Head sampled by the sondes generally had recently flowed ashore from over the Pacific Ocean, but frequently that air 
had traveled substantial distances over North America. Similarly, after sampling the air generally flowed east over North America, but frequently returned to the Pacific. In summary, the trajectory analysis supports the hypothesis that the Trinidad Head sondes generally sampled air flowing ashore from the Pacific followed by transport inland, such as over the Northern Sacramento Valley, but there certainly is no implication of consistent transport from Trinidad Head directly to the NSV.

It is important to note that on the relatively few occasions that trajectory segments pass over portions of the continent before arriving at Trinidad Head does not necessarily indicate that air has experienced continental influence. The trajectories do remain in the free troposphere, and are generally isolated from continental boundary layer influence.

The trajectory calculations presented here, as well as all trajectory calculations, are subject to significant errors. The trajectories are necessarily calculated from large scale, relatively coarse grid meteorological data. These data are suitable for evaluation of general large-scale flow patterns, but not for defining specific, mesoscale flow patterns. To our knowledge there are no other available meteorological data sets that would reveal more detailed information regarding the transport of air masses sampled by the $\mathrm{O}_{3}$ sondes.

\section{A2 North American influence on air sampled by Trinidad head ozone sondes}

Figure $\mathrm{A} 3$ presents carbon monoxide (CO) profiles measured above Trinidad Head. $\mathrm{CO}$ concentrations elevated above the global background are a sensitive indicator of recent anthropogenic pollutant emissions. Occasional $\mathrm{CO}$ enhancements are seen within the BL, which are expected from the landsea breeze circulation as discussed in detail by Parrish et al. (2009). CO enhancements are not observed in the 1$2.5 \mathrm{~km}$ altitude range, which is the focus of the present study. Substantial CO enhancements are seen at higher altitudes; they are likely of Asian origin and the surface ozone does not correlate with ozone observed at this altitude. To our knowledge, with the exception of infrequent forest fire plumes (e.g. Weiss-Penzias et al., 2007), there is no evidence that California emissions can be circulated over the Pacific and return to the California coast above the MBL. The CO profiles measured over Trinidad Head show no evidence for such recirculation. This lack of evidence is expected because (in the absence of thermal lofting of forest fire plumes) it is very difficult to envision summertime mechanisms for export of polluted air from the California continental BL to the marine FT against the prevailing onshore airflow.

In Fig. A3 the $\mathrm{CO}$ measured aloft in the $1-2.5 \mathrm{~km}$ altitude range agrees well with the global background $\mathrm{CO}$ concentration determined from the NOAA ESRL Global Monitoring Division flask network for the latitude, season and years of the aircraft $\mathrm{CO}$ measurements. This indicates that the air sampled by the sondes in the $1-2.5 \mathrm{~km}$ altitude range does

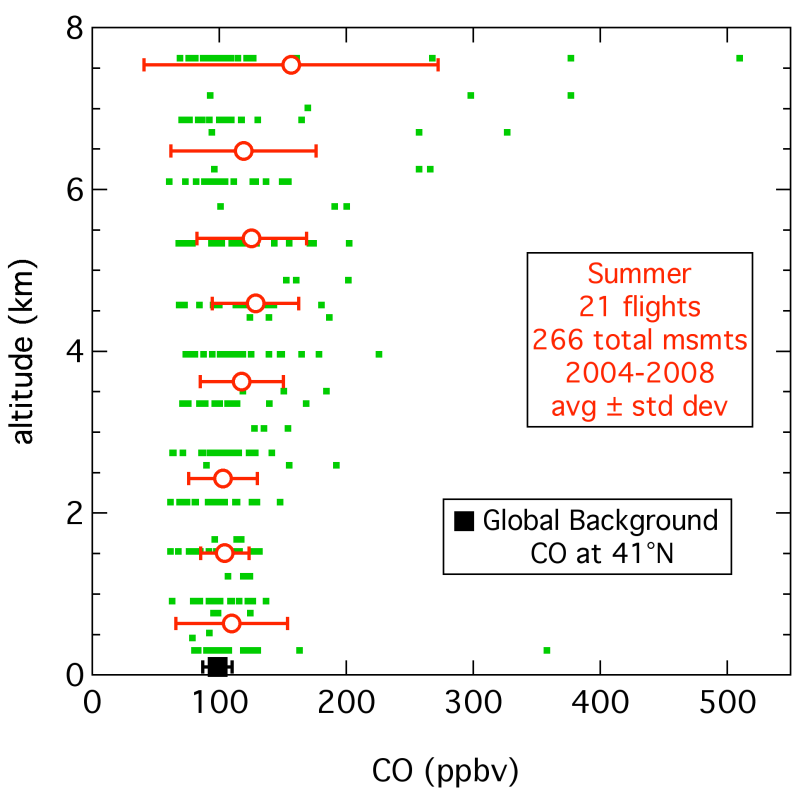

Fig. A3. Vertical profiles of carbon monoxide measured in flasks collected on aircraft flights above Trinidad Head CA. The green points give the individual measurements, and the red circles indicate averages and standard deviations for $1 \mathrm{~km}$ altitude segments. The black symbol gives the surface global carbon monoxide background as determined from the NOAA ESRL Global Monitoring Division flask network for the years of the aircraft measurements (Paul Novelli, NOAA ESRL Global Monitoring Division, personal communication, 2009).

represent background northern mid-latitude air, without discernable direct $\mathrm{CO}$ influence from North America. In photochemically well-processed air masses in summertime, any $\mathrm{O}_{3}$ enhancements from relatively local continental sources are expected to be only a fraction of the $\mathrm{CO}$ enhancements (see, e.g. Parrish et al., 1998). Thus, the air sampled by the sondes in the $1-2.5 \mathrm{~km}$ altitude range does represent background northern mid-latitude air with respect to $\mathrm{O}_{3}$ as well as CO.

Acknowledgements. The authors gratefully acknowledge the NOAA Air Resources Laboratory (ARL) for the provision of the HYSPLIT transport READY website (http://www.arl.noaa.gov/ready.html) used in this publication.

Edited by: T. Karl

\section{References}

Dillon, M. B., Lamanna, M. S., , Schade, G. W., Goldstein, A. H., and Cohen, R. C.: Chemical evolution of the Sacramento urban plume: Transport and oxidation, J. Geophys. Res., 107(D5), 4045, doi:10.1029/2001JD000969, 2002. 
Draxler, R. R. and Rolph, G. D.: HYSPLIT (HYbrid Single-Particle Lagrangian Integrated Trajectory) Model access via NOAA ARL READY Website (http://www.arl.noaa.gov/ready/hysplit4.html), NOAA Air Resources Laboratory, Silver Spring, MD, 2003.

Fiore, A. M., Jacob, D. J., Bey, I., Yantosca, R. M., Field, B. D., Fusco, A. C., and Wilkinson, J. G.: Background ozone over the United States in summer: Origin, trend, and contribution to pollution episodes, J. Geophys. Res., 107(D15), 4275, doi:10.1029/2001JD000982, 2002.

Fiore, A., Jacob, D. J., Liu, H., Yantosca, R. M., Fairlie, T. D., and Li, Q.: Variability in surface ozone background over the United States: Implications for air quality policy, J. Geophys. Res., 108, 4787, doi:10.1029/2003JD003855, 2003.

Huang, M., Carmichael, G. R., Adhikary, B., Spak, S. N., Kulkarni, S., Cheng, Y. F., Wei, C., Tang, Y., Parrish, D. D., Oltmans, S. J., D’Allura, A., Kaduwela, A., Cai, C., Weinheimer, A. J., Wong, M., Pierce, R. B., Al-Saadi, J. A., Streets, D. G., and Zhang, Q.: Impacts of transported background ozone on California air quality during the ARCTAS-CARB period - a multi-scale modeling study, Atmos. Chem. Phys., 10, 6947-6968, doi:10.5194/acp-106947-2010, 2010.

Hudman, R. C., Jacob, D. J., Cooper, O. C., et al.: Ozone production in transpacific Asian pollution plumes and implications for ozone air quality in California, J. Geophys. Res., 109, D23S10, doi:10.1029/2004JD004974, 2004.

Liu, G., Tarasick, D. W., Fioletov, V. E., Sioris, C. E., and Rochon, Y. J.: Ozone correlation lengths and measurement uncertainties from analysis of historical ozonesonde data in North America and Europe, J. Geophys. Res., 114, D04112, doi:10.1029/2008JD010576, 2009.

McKendry, I. G., Hacker, J. P., Stull, R. B., Sakiyam, S., Mignacca, D., and Reid, K.: Long-range transport of Asian dust to the Lower Fraser Valley, British Columbia, Canada, J. Geophys. Res., 106(D16), 18,361-18,370, 2001.

Murphy, J. G., Day, D. A., Cleary, P. A., Wooldridge, P. J., and Cohen, R. C.: Observations of the diurnal and seasonal trends in nitrogen oxides in the western Sierra Nevada, Atmos. Chem. Phys., 6, 5321-5338, doi:10.5194/acp-6-5321-2006, 2006.

Myrup, L. O., Morgan, D. L., and Boomer, R. L.: Summertime three-dimensional wind field above Sacramento, California, J. Climate Appl. Meteor., 22, 256-265, 1983.

Neri, F., Saitta, G., and Chiofalo, S.: An accurate and straightforward approach to line regression analysis of error-affected experimental data, J. Phys. E Sci. Instrum, 22, 215-217, 1989.
Press, W. H., Teukolsky, S. A., Vetterling, W. T., and Flannery, B. P.: Numerical Recipes in C, 2nd edn., Cambridge Univ. Press, New York, USA, 1992.

Oltmans, S. J., Lefohn, A. S., Harris, J. M., and Shadwick, D. S.: Background ozone levels of air entering the west coast of the US and assessment of longer-term changes, Atmos. Environ., 42, 6020-6038, 2008.

Parrish, D., Trainer, M., Holloway, J., Yee, J., Warshawsky, M., Fehsenfeld, F., Forbes, G., and Moody, J.: Relationships between ozone and carbon monoxide at surface sites in the North Atlantic region, J. Geophys. Res., 103(D11), 13357-13376, 1998.

Parrish, D. D., Kondo, Y., Cooper, O. R., Brock, C. A., Jaffe, D. A., Trainer, M., Ogawa, T., Hübler, G., and Fehsenfeld, F. C.: Intercontinental Transport and Chemical Transformation 2002 (ITCT 2K2) and Pacific Exploration of Asian Continental Emission (PEACE) experiments: An overview of the 2002 winter and spring intensives, J. Geophys. Res., 109, D23S01, doi:10.1029/2004JD004980, 2004.

Parrish, D. D., Millet, D. B., and Goldstein, A. H.: Increasing ozone in marine boundary layer inflow at the west coasts of North America and Europe, Atmos. Chem. Phys., 9, 1303-1323, doi:10.5194/acp-9-1303-2009, 2009.

Rolph, G. D.: Real-time Environmental Applications and Display sYstem (READY) Website (http://www.arl.noaa.gov/ready/ hysplit4.html), NOAA Air Resources Laboratory, Silver Spring, MD, 2003.

Trainer, M., Williams, E. J., Parrish, D. D., Buhr, M. P., Allwine, E. J., Westberg, H. H., Fehsenfeld, F. C. and Liu, S. C.: Models and observations of the impact of natural hydrocarbons on rural ozone, Nature, 329, 705-707, 1987.

US Environmental Protection Agency: Air quality criteria for ozone and related photochemical oxidants, v. I-III, Office of Research and Development, Research Triangle Park, NC, 2006.

Weiss-Penzias, P., Jaffe, D., Swartzendruber, P., Hafner, W., Chand, D., and Prestbo, E.: Quantifying Asian and biomass burning sources of mercury using the $\mathrm{Hg} / \mathrm{CO}$ ratio in pollution plumes observed at the Mount Bachelor observatory, Atmos. Environ., 41, 21, 4366-4379, doi:10.1016/j.atmosenv.2007.01.058., 2007.

Zhong, S. Y., Whiteman, C. D., and Bian, X. D.: Diurnal evolution of three-dimensional wind and temperature structure in California's Central Valley, J. Appl. Meteorol., 43, 1679-1699, 2004. 